\title{
Silvicultural prescriptions for mixed-species forest stands. A European review and perspective
}

\author{
Hans Pretzsch ${ }^{1}$ (D) Werner Poschenrieder ${ }^{1} \cdot$ Enno Uhl $^{1,2} \cdot$ Gediminas Brazaitis $^{3} \cdot$ Ekaterina Makrickiene $^{3}$. \\ Rafael Calama ${ }^{4}$
}

Received: 14 January 2021 / Revised: 29 April 2021 / Accepted: 22 May 2021 / Published online: 21 June 2021

(c) The Author(s) 2021, corrected publication 2021

\begin{abstract}
Compared with far-developed measures and methods for mono-specific forest stands, the silvicultural prescriptions for mixed-species stands are at their early beginning. However, they are essential for the well-conceived establishment, design, and control of mixed-species stands, currently promoted in many countries worldwide. Here, we review the state of the art and we further develop silvicultural prescriptions for mixed-species stands for steering of experiments, stand modeling, and silviculture. We review which aspects of tree species mixing are most relevant for management goal achievement. We found the maintenance of species diversity and structural heterogeneity for ecological purpose, stabilizing productivity, and social-economic performance as main objectives. We give an overview of quantitatively formulated silvicultural prescriptions for steering mixed-species stands for forest practice, long-term experiments, forest stand models. Compared with the sophisticated guidelines for mono-specific stands, prescriptions for mixed stand are often mainly qualitative and vague. Then, we introduce methodological approaches in development for steering mixture: measures for spatial and temporal separation, species-specific growing space requirements for crop trees, coefficients for equivalence and density modification, and basic relationships for steering tree number and area-based mixing proportions. Finally, we draw conclusions for further development of methodological approaches for silvicultural steering of experiments, implementation in stand simulators, and for silvicultural operations. We see the need for improving the quantitative spatially explicit rules based at tree or cohort level, for substantiating the knowledge on species-specific allometry, growing area, tree-to-tree distances, and position-dependent competition indices for steering tree removal. We discuss the prospects and limitations of establishing silvicultural prescriptions for mixed-species stands that inevitably will be more complicated than those for mono-specific stands, and we draw conclusions for next steps in science and practice.
\end{abstract}

Keywords Species-mixing experiments · Thinning algorithms · Temporal and spatial separation - Equivalence coefficients . Silvicultural steering $\cdot$ Individual tree models $\cdot$ Scenario analyses

Communicated by Peter Biber.

Hans Pretzsch

Hans.Pretzsch@tum.de

1 Chair for Forest Growth and Yield Science, School of Life Sciences, Technical University of Munich, Hans-Carl-von-Carlowitz-Platz 2, 85354 Freising, Germany

2 Bavarian Institute of Forestry, Hans-Carl-von-Carlowitz-Platz 1, 85354 Freising, Germany

3 Institute of Forest Biology and Silviculture, Vytautas Magnus University Studentu, str. 11 Akademijos mstl. Kaunas dist. LT-53361, Lithuania

4 Department of Forest Dynamics and Management, INIA-Forest Research Centre. iuFOR UVa-INIA, Ctra. A Coruña km 7.5, 28040 Madrid, Spain

\section{Introduction. Motivation and objectives}

In many regions of the world, mixed-species stands are discussed as management option and are on the advance (Bravo-Oviedo et al. 2014). Especially under environmental changes, they seem to provide many ecosystem services better than monocultures (Jactel et al. 2018). Many recently published works improve the understanding of the spatial structure, intrinsic mechanisms, and dynamics of mixedspecies stands. A state of knowledge has been provided among others by the monographs by Bravo-Oviedo et al. (2018a), Pretzsch et al. (2017) and previous contributions by Scherer-Lorenzen et al. (2005), Olsthoorn et al. (1999), and Kelty (1992). A broad overview of interactions between 
tree species and mixing effects on growth provided the metaanalyses and big data analyses by Jactel et al. (2018), Liang et al. (2016), and Piotto et al. (2008) and the modeling studies by Morin et al. (2011), Gonzalez de Andres et al. (2017), and Rötzer et al. (2009). However, we found hardly research into quantitative prescriptions for the design of mixed-species stands. There is a lack of know-how to parameterize silvicultural guidelines for mixed-species stands, how to develop sufficiently simplistic rules for steering long-term experiments on a standardized basis, to implement silvicultural guidelines into simulation models and to introduce quantitatively based silvicultural steering of mixed-species stands into forest practice (Brzeziecki et al. 2021, Bravo et al. 2019, Bielak et al. 2014, Coll et al. 2018, Mason et al. 2018). Notice that for reason of clarity throughout the whole review, we define some essential terms such as "silvicultural interventions," "silvicultural prescription," "algorithm," "regulation" or "steering" Glossary Box 1.

In contrast with mono-specific stands, silvicultural interventions in mixed-species stands may be imperative to maintain a species or desired species composition and to achieve a defined target state. In many cases, interventions according to silvicultural prescriptions are highly necessary to guarantee the coexistence of various species and the maintenance of a given tree species composition. Despite of many advantages of mixed versus mono-specific stands, there are still hurdles to advance with their spread (Nichols et al. 2006). One reason may be the lack of common guidelines for the successful application of interventions in experiments, models and practical forest management (Kelty and Cameron 1995, p. 328). Latter authors suggested to add complexity to the steering and analysis of mixed-species stands, e.g., to introduce more complicated approaches of species-specific mixing pattern and proportions.

The few studies on silvicultural prescriptions of mixed stands are often derived from mono-specific stands and do not sufficiently consider that mixed stands are more than only the weighted means of the respective mono-specific stands (Forrester 2014). In mixed stands, the maximum stand density can be different from monocultures (Ducey et al. 2017; Pretzsch and Biber 2016), the tree species can have different growing space requirements (Ammer 2008; Juchheim et al. 2017), and the growth rhythms may differ per se between species (Mitscherlich 1970) due to emergent mixing effects (Pretzsch and Zenner 2017; Pretzsch et al. 2015c). Available prescriptions are often just qualitatively and vaguely formulated. As long as just qualitatively formulated, they may be difficult to parametrize for practical

Glossary Box 1 Overview of the main terms used in this review, their definition and respective references

\begin{tabular}{|c|c|c|}
\hline Term or concept & Definition/explanation & Source/References \\
\hline Density equivalence coefficient & $\begin{array}{l}\text { A mathematical expression assessing the stand density and growing area } \\
\text { requirement for one species in relation to the requirement of other species, } \\
\text { assuming the same diameter }\end{array}$ & Pretzsch and del Río (2020) \\
\hline Equivalence coefficients & $\begin{array}{l}\text { Coefficients that allow to convert the size, growing area, or competitive effect } \\
\text { of one species into the other }\end{array}$ & Begon et al. 1998, pp. $177-180$ \\
\hline Regulation & $\begin{array}{l}\text { Guiding or controlling the development of a forest system based on the initial } \\
\text { conditions, the time exogenous variables } \\
\text { and dynamic rules that can be modified as a function of the current develop- } \\
\text { ment of the system }\end{array}$ & Berg and Kuhlman (1993) \\
\hline Silvicultural prescription & $\begin{array}{l}\text { A planned series of treatments designed to change current forest structure to } \\
\text { one meeting the goals and objectives established for an area }\end{array}$ & Helms (1998) \\
\hline Steering & $\begin{array}{l}\text { Guiding or controlling the development of a forest system based on the initial } \\
\text { conditions, the time exogenous variables and static rules (e.g., guide-curve) }\end{array}$ & Berg and Kuhlman (1993) \\
\hline Thinning & $\begin{array}{l}\text { Intermediate cuttings used to modify the growth, quality, vigor, composition, } \\
\text { or structure of a forest stand after its establishment and prior to its final } \\
\text { harvest }\end{array}$ & Assmann (1970) \\
\hline Thinning algorithm & $\begin{array}{l}\text { Set of instructions programmed within the forest simulation model aiming to } \\
\text { the automatic selection of the trees to be thinned by specification of thinning } \\
\text { concept, thinning strength and thinning interval }\end{array}$ & Fabrika and Dursky (2005) \\
\hline Thinning experiment & $\begin{array}{l}\text { A manipulative experiments focusing on modifying composition, density } \\
\text { and spatial arrangement of the individuals by means of cutting, in order to } \\
\text { observe a response in terms of growth \& productivity or any other dynamic } \\
\text { or functional process. Levels of thinning must be randomized, replicated and } \\
\text { objectively reproducible, while environmental conditions should be kept as } \\
\text { constant as possible }\end{array}$ & Larocque et al. (2013) \\
\hline Treatment rule & $\begin{array}{l}\text { Basic unit for describing a single forest intervention, comprising locational } \\
\text { and temporal aspects, strength definition and procedure description. A set of } \\
\text { sequential treatment rules define a silvicultural prescription }\end{array}$ & $\begin{array}{l}\text { Schwaiger et al. (2018), } \\
\text { Nyland (2016) }\end{array}$ \\
\hline
\end{tabular}


use and also difficult to control. A quantitative formulation is also required for their translation into algorithms and integration into simulation models for prognosis and planning, analogous to the algorithms for the treatment of monospecific stands (Pretzsch et al. 2015a). Such quantitative silvicultural prescriptions may subsequently promote the transition from the analysis to the design of mixed-species stands and their increased implementation and successful regulation. They are essential for the well-conceived establishment, the design and control of mixed-species stands, promoted in many places. This is the reason to review the state of the art of silvicultural prescriptions in mixed-species stands for practical silviculture, steering of experiments, and modeling.

To review and advance with the silvicultural prescriptions for mixed-species forest stands, our overall aims were: (i) to review which aspects of tree species mixing are most relevant for management goal achievement (Sect. "General considerations about silvicultural prescriptions for forest management"), (ii) to summarize the available concepts and prescriptions for the silvicultural steering of mixedspecies stands in experiments, models, and forest practice (Sect. "Steering and regulating tree species mixture in experiments, models, and forest practice"), (iii) to introduce new methodological approaches for steering mixture and develop perspectives for moving forward with quantitative guidelines (Sect. "Challenges, objectives, and concepts for further development of silviculturalprescriptions for mixed-species stands"). Finally, we conclude how to advance with quantitatively based silvicultural prescriptions for regulation and steering of tree species mixtures in models, experiments, and forest practice (Sect. "Conclusions").

This review considers mainly mono-layered and evenaged mixed-species stands (Nyland 2016, p. 31). In this sense, we will include mixtures where the different tree species may occupy slightly different canopy levels, e.g., stands with dominating pine and subdominant oak. We will deal with stands in which the mixed species are maintained over the whole rotation, as they have increasing relevance in Europe (Bravo-Oviedo et al. 2018a; Brus et al. 2012). We also will not consider the regeneration process, but deal with prescriptions that start with established stands with various spatial and temporal configurations of initial structure, and that end with the final harvest. Finally, we will focus on both human-created and naturally established mixtures and on appropriate silvicultural prescriptions in order to achieve defined objectives (e.g., stress resilience, tree species diversity, level, and temporal stability of productivity). This review deals with the silvicultural prescriptions defined for the stand level and realized by intervening at the individual tree level; it will not consider the landscape level.

We first review which aspects of tree species mixing and silvicultural criteria are most relevant for goal achievement of forest management (Sect. "General considerations about silvicultural prescriptions for forest management"). Then, we give an overview of quantitatively formulated silvicultural prescriptions for steering mixed-species stands in forest practice, on long-term experiments, and in forest models (Sect. "Steering and regulating tree species mixture in experiments, models, and forest practice"). We subsequently introduce new approaches for steering mixtures (Sect. "Challenges, objectives, and concepts for further development of silviculturalprescriptions for mixed-species stands") and finally draw conclusions for the next steps in science and practice (Sect. "Conclusions"). Note, that this publication provides Online Supplementary Material for further information.

\section{General considerations about silvicultural prescriptions for forest management}

\section{Knowledge for target achievement}

Silvicultural prescriptions aim at the development of forest stands from a current state to a target state, e.g., they may recommend how to maintain a mixture in a stand from the early to the late development state or how to transform a monoculture of Norway spruce to a mixed-species stand of Norway spruce and beech. In this way, silvicultural prescriptions essentially contribute to forest ecosystem management. If we assume a particular actual state of a forest, e.g., a pure Norway spruce stand, then forest ecosystem management involves the development of a target state for the system, and the transformation of the actual, into the target state (Fig. 1). The definition of a target state, in our example a mixed Norway spruce and European beech stand, results from negotiations among the people concerned, e.g., forest owners, stakeholders, NGOs. In the figure, the negotiation process is symbolized by the round table that has become common for participative development of management plans. If the target state is defined clearly and formulated quantitatively, practical rules can be developed as guidelines for the realization of the target transformation (feedback loop in the middle of Fig. 1).

The concept presented in Fig. 1 reveals the two most promising gateways for introducing scientific knowledge into forest ecosystem management. The first is the supply of target knowledge for the development of objectives, e.g., deciding which species mixture would optimize the expected forest functions and services in a municipal forest. Of primary interest may be, for instance, recreation options or stand stability in the face of storms given the forest's vicinity to houses. The second gateway for scientific knowledge transfer is the supply of transformation knowledge by silvicultural prescriptions. This follows after setting an objective, 


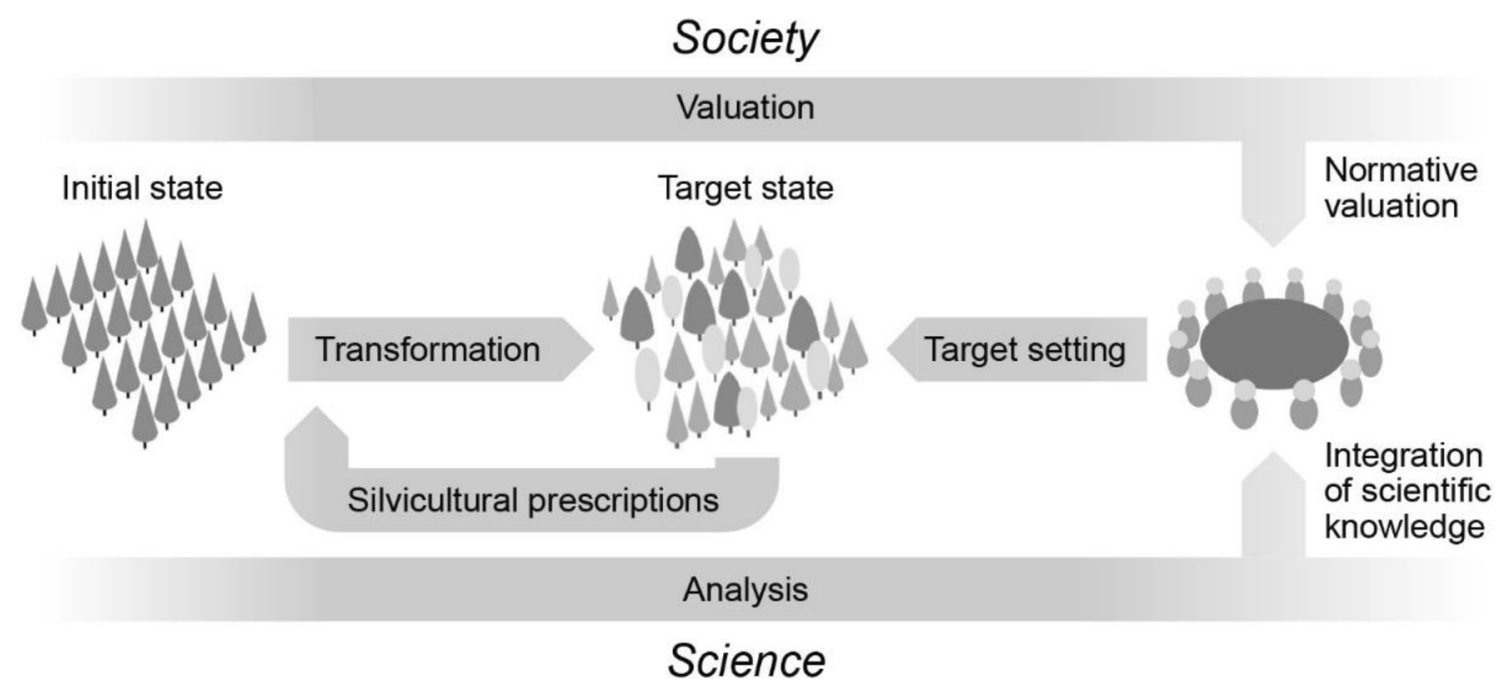

Fig. 1 Concept for forest management and the role of silvicultural prescriptions for practical transformation of initial stands to target states. Given an initial state (forest stand, landscape unit), the aim of

e.g., which practice to use to transform a pure stand into a mixed stand, which stand thinning regime to use so that a maximum number of trees with a prescribed threshold diameter can be harvested, or which stand treatments should be implemented to maximize stability against wind-throw. For both gateways simulation models, appropriate for mixedspecies stands are essential (see Sect. "The principles of regulation and steering for the development and application ofsilvicultural prescriptions").

Silvicultural prescriptions represent the knowledge how to design and transform forest stands in order to achieve a given management target. They certainly depend on both, the current state of a forest and the target stand. As the silvicultural prescriptions should support the transformation of an initial, current stand to a target state, they should be specific and unambiguous enough to reach the target but also simple enough to be practically realizable. Silvicultural prescriptions may be based on setpoint measures and variables that are relatively easy to assess in forest stands.

\section{Relevance of tree species mixture for target achievement}

Tree species mixing can be an efficacious method for achieving defined silvicultural targets in the course of forest ecosystem management (Fig. 1), but it requires well-conceived design.

Tree species mixing may cause an improvement in biomass growth in plantations by admixture of nitrogen-fixing species, e.g., Acacia sp. (Bauhus et al. 2000; Bristow et al. 2006; Forrester et al. 2005). It is also as a well-known benefit of tree species mixing that stem shape and wood quality of sessile and common oak may be promoted by mixed forest management is to transform a system into a target state. The normative values of society and scientific knowledge contribute to the development and achievement of the objective

species such as European beech, hornbeam, or lime tree (Andrzejczyk and Brzeziecki 2018; Attocchi 2015; Hochbichler 1993) but decrease in the absence of them (Kerr 1996). Another very current example is the stand stabilization against various damages (Bauhus et al. 2017). Conifer stands may become more resistant against windthrow and pests by admixture of broadleaved species such as European beech (Keane et al. 2018; Griess and Knoke 2011; Neuner et al. 2015).

However, when two, three, or even more initially promising species are mixed, they often compete with each other in an undesirable way. With proceeding stand development, more dominant species may suppress or even outcompete others (Pretzsch and Zenner 2017). Silvicultural interventions may become necessary in order to maintain a defined mixture proportion per species over the whole rotation (Kairiūkštis and Juodvalkis 2005). For example, birch in mixture with spruce (Fahlvik et al. 2015; Felton et al. 2010) or pine in mixture with oak (Mosandl and Kleinert 1998, Pretzsch et al. 2019a, b, 2020) may need long-term promotion in order to keep a desired tree number proportion and quality.

The maintenance of tree species mixing throughout a rotation may require continuous thinning (Fig. 2). For example, in the mixed stands of Norway spruce and European beech in Oderhaus/Northern Germany, height growth (Fig. 2a) of beech is so inferior to spruce that it needs permanent release from competing spruces in order to be kept in the play. This may result in a reduction in the stand density and standing volume of the mixed stand far below the level of the pure stand (N.sp.+E.be. versus N.sp. pure, see Fig. 2b). Another common example is the competitive imbalance between European beech and sessile oak on many 


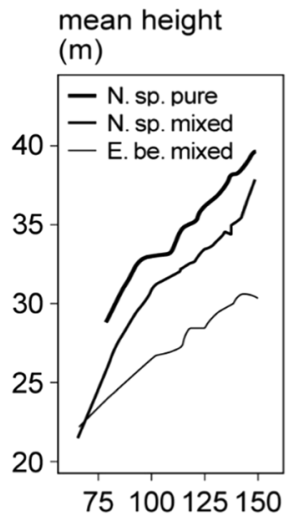

(a)

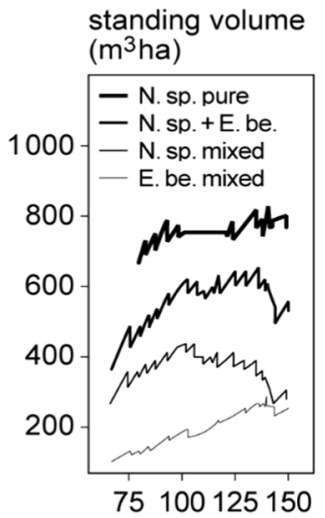

(b)

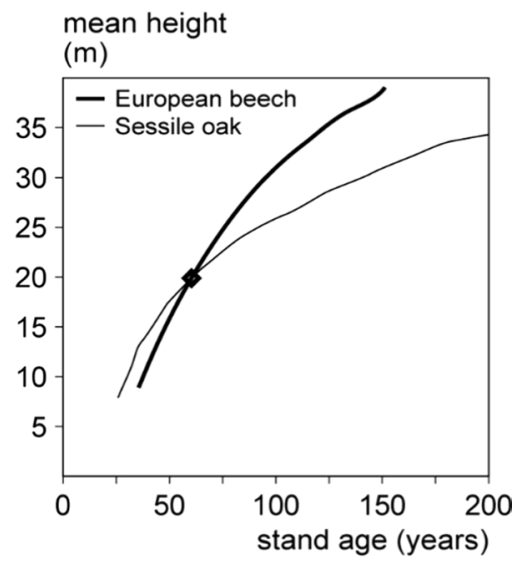

(c)
Fig. 2 Examples for inter-specific competition that may require silvicultural interventions in order to keep both species in the stand. (a and b) On the long-term mixing experiment of Norway spruce and European beech (Oderhaus/Harz, Lower Saxony), European beech is inferior to spruce in height growth (a) and needs permanent promotion by removal of competing spruces $(\mathbf{b})$. (c) On the mixing experi-

sites in Central Europe (see e.g., Andrzejczyk 2009, p 176) indicated by the intersection of their species-specific height growth curves at about age 50 (Fig. 2c). If not controlled by thinning, European beech may over-top and outcompete the accompanying species in mixed stands. In naturally established mixed stands, the tree species composition must be heavily regulated during initial stages, as without early promotion of the initially slower growing species these are outcompeted or after delayed thinnings shifted to a secondary layer (Kairiūkštis and Juodvalkis 1985).

\section{The main criteria of thinning interventions}

Initially, thinning was defined for mono-specific stands at the stand or tree cohort level (Schwappach 1908, 1911; Wiedemann 1951) or individual tree level (Nyland 2016; Kerr and Haufe 2011; Schädelin 1942). For the main criteria, variants and measures for defining and quantifying thinning interventions according to Assmann $(1961,1970)$ and Abetz and Mitscherlich (1969) (see Supplement Table 1). When moving from monocultures to mixed stands, the potential range of thinning methods and variants is significantly enlarged and variants and measures need to be defined for each of the main tree species or species groups in the stand specifically.

The most important basic concepts for kind, strength, and frequency of thinning and their extensions to mixed-species stands are visualized in Fig. 3.

Figure 3a shows a geometric thinning by removal of every 2nd row in monospecific stands. Extension of this method is applied in mixed stands where species are planted in single species clusters or strips consisting of several rows, and ments of European beech and sessile oak in Steigerwald in Bavaria, European beech may overtop and outcompete sessile oak beginning at age 50 , if not controlled by thinning. N. sp. pure, Norway spruce in pure stand; N. sp. mixed, Norway spruce in mixed stand; E. be. mixed, European beech in the mixed stand; N.sp. +E.be. mixed stand of Norway spruce and European beech in total

the edge row mostly outcompeted/overcompeted is eliminated (for example, Scots pine and birch mixture in bands of 5-9 single species rows where the exterior birch rows are eliminated) (Jaworski 2012; Juodvalkis and Kairiūkštis 2009). As common examples for a schematic type of thinning in mixtures, we can mention the promotion of one species by the removal of the individuals of the second species located within a predefined critical distance (Fig. 3b) and the schematic removal of all the individuals of species 2 within groups of species 1 (Fig. 3c). Such interventions are common and in younger stands are essential in order to regulate the tree species proportions if one species might be outcompeted by the other. Examples are the promotion of sessile oak or Scots pine by removal of competing European beech (Stimm et al. 2021; Spellmann 2008), promotion of Pyrenean oak when mixed with Scots pine (GonzálezMolina 1996), and release of slower growing Norway spruce when mixed with naturally regenerated birch, aspen, and grey alder (Kairiūkštis 1973). In all the cases, in order to keep the mixtures the light demanding species (such as Scots pine, sessile oak, or European larch) often need a promotion by schematic release or selective treatment (based on negative selection) of neighboring more shade-tolerant species (Hilmers et al. 2020).

In monocultures, the strength of thinning is often quantitatively defined at the stand level by a guide curve relating number of standing trees per ha with average tree diameters (Fig. 3d). Another option is the selection of a defined number of future crop trees (Abetz 1974) and to propose the release by removal of a defined number of neighbors. Similar methods may be proposed for mixed stands, but taking 

strength, and frequency of thinning further developed from monospecific to mixed-species stands. (a-c) From geometric elimination of every second row in monospecific stands to species from competitors in individual tree or group mixture. (d-f) From density reduction based on tree number stem diameter trajectories to species-specific density reduction by future crop tree (black) selection and removal of their neighbors (white and marked with a cross when removed). (g-i) From frequency of thinning determined by height growth in mono-specific stands to species-specific tree numberheight guidelines and interventions based on vertical crown competition
Fig. 3 Descriptions of kind, schematic release of a preferred



(a)

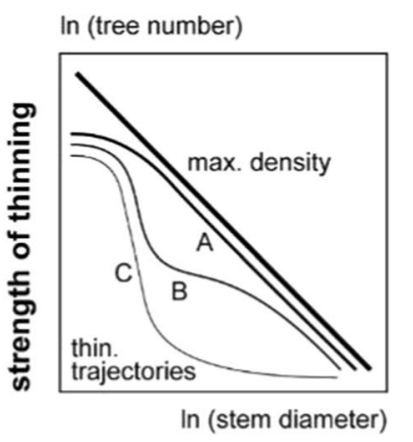

(d)

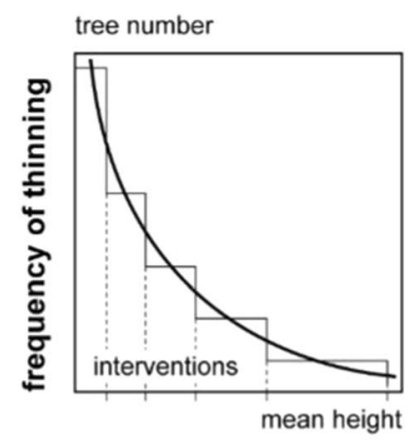

(g)

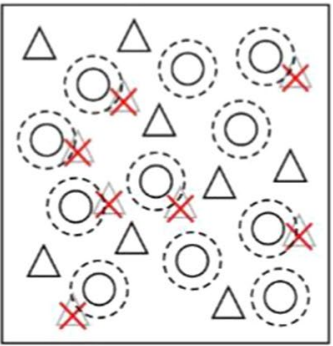

(b)

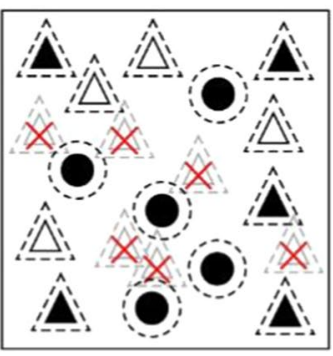

(e)

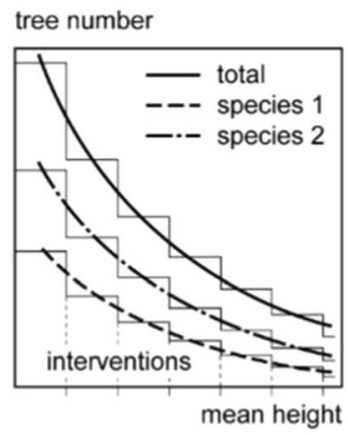

(h)

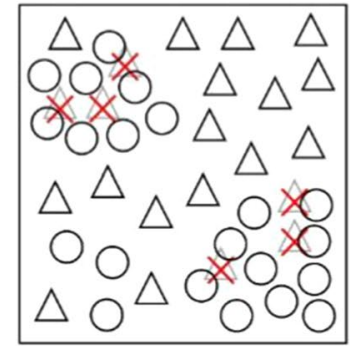

(c)



(f)



(i) into account the number of trees per species to be released / removed. As an example, although initial conditions of mixtures presented in Figs. $3 e$ and $f$ are similar, in Fig. 3e the selection of crop trees aims at a balanced mixing proportion (50:50) between two species, while the situation in Fig. $3 \mathrm{f}$ aims at the promotion of the species indicated by triangles by both selection of a higher number of crop trees and their stronger release.

Figure $3 \mathrm{~g}-\mathrm{i}$ finally provides examples how the frequency of thinning interventions may be scheduled by stand age or even better by mean height or diameter in mixed stands in contrast with monospecific stands. A very common schedule for thinning frequency is based on a tree number-mean tree size attribute (mean height or mean diameter) curve as shown in Fig. 3g. Based on this, the frequency of interventions may be scheduled by mean height (or diameter intervals), i.e., the height or mean squared diameter growth is used as measure for the timing of interventions (Abetz 1988). This makes sense, as the tree growth determines the inter-individual competition; on rich site where growth proceeds faster, dimensions planned for interventions are achieved earlier, so that the frequency is higher than on poor sites with slower development and delayed inter-individual competition. In mixed-species stands, the thinning frequency may be scheduled based on the same principle, but the setpoint tree number must be defined separately for each tree species separately and also for the stand in total (Fig. 3h). Another option of a biologically scheduled intervention 
frequency is shown in Fig. 3i. In this case, it is taken into account that every species has individual characteristics on shade tolerance and height growth within shade gradient differs reaching highest growth under partial shade conditions (Kairiūkštis and Juodvalkis 1985). In order to spare species 1 from being altered by crown shading of species 2 , the interventions might be scheduled depending on the critical height difference between both species or on the difference between the height to crown based of species 1 and the tree height of species 2; interventions may be prescribed as soon as species 2 approaches the crown space of species 1 . In this way, the dynamic of both species and their relative strength in terms of height growth is used as biological indicator for scheduling the frequency of thinning.

\section{Steering and regulating tree species mixture in experiments, models, and forest practice}

\section{Quantitative concepts for experiments}

There are many suggestions for designing plantations for tree species mixtures by combined spacing and mixing patterns (Goelz 2001; Harper 1977; Vanclay et al. 2013; Vanclay 2006; Kelty and Cameron 1995). It is amazing that many of such studies do not address the silvicultural operations, although many of them will require such treatment in advanced stages (Amoroso and Turnblom 2006; Erickson et al. 2009; Forrester 2014; Forrester et al. 2006). Thus, these publications are supportive for establishing mixed stand trials, but they hardly tell anything about how to experimentally steer the treatment variants after stand establishment.

Thinning experiments on mixed stands focus on modifying composition, density, and spatial arrangement of the individuals in order to observe a response in terms of growth and productivity or any other dynamic or functional process, commonly considering most advanced stages of stand development. In this case, the intrinsic heterogeneity of natural forests, the large number of potential combinations, and the difficulty for attaining the predefined levels of each factor deepens the complexity for the establishment of complete replicated experiments, e.g., comparing different rates of proportion under the same stocking level or the same rate of proportion under different stocking levels.

The examples in Table 1 represent the main common concepts for regulating the kind, strength, and frequency of interventions in mixed-species experiments.

The kind of thinning is mostly thinning from above defined by the removal of social tree classes (Kairiūkštis and Juodvalkis 1985; Kennel 1965; Pretzsch 2009). The pattern of tree removal is either schematic (removals of rows) or selective (removal of competing neighbors) (Piotto et al.
2003). In case of mixing in groups or clusters, prescriptions focus on determining patch size and number of trees per species in a patch (Kennel 1965). If all tree coordinates are available, the spatial arrangement may be quantified by indices for the spatial tree distribution (del Rio et al. 2016, Pommerening 2002) or Ripley's K-function at the whole stand and species level (Pretzsch 2009, pp. 256-266).

The strength of thinning is defined by set point tree numbers (Hynynen et al. 2011, Piotto 2003), basal area (Aldea et al. 2017, de-Dios-García et al. 2015), or standing volume (Beliajeva and Ischuk 2010; Danilov et al. 2014; Jacobsen and Thorsen 2003; Lundqvist et al. 2014; Zalesova et al. 2016). The removal results from the reduction in the standing stock to the set point level. The set point level is defined for each tree species separately. In this way, a desired mixing proportion can be achieved. The mixing proportions may be quantified based on tree number, stand basal area, SDI, or stand volume; the results can differ considerably in mixtures with different species-specific growing area requirements (Dirnberger and Sterba 2014).

The frequency of thinning is mainly defined through the time interval in years (Hynynen et al. 2011) or the development of tree size (Kairiūkštis and Juodvalkis 1985). Compared with the silvicultural prescriptions and guidelines for practice and forest management, the quantitative assessment and prescriptions for experiments in mixed stands are often more complex and detailed and may require previous calculations. For instance, the species-specific basal area and stem positions of the total stand may be inventoried first in order to calculate the setpoint of the removal basal area per species and the number of removed competitors around preselected future crop trees.

The simple proportion by stem number per ha or basal area is not meaningful in the case tree species have not the same size or potential site growth (Dirnberger and Sterba 2014). As way out, Pretzsch and del Río (2020) proposed to compute the mixing proportions of species with different growing area requirements based on equivalence coefficients as the ratio between species maximum SDI (or basal area) observed in fully stocked monospecific stands. In this sense, Nowak (1995) proposed an approach for designing thinning experiments in mixed forests based on prescribing a final relative density or basal area (percentage with respect to the observed maximum density) and a target mixed proportion which is computed taking into account the frequencies of the diameter distribution of each species within the stand.

A more detailed quantitative description of mixture proportions is based on describing tree-level between and within species competition using spatial indices as area potential available (APA), describing the growing space for each tree by means of Voronoi diagrams (Brown 1965; Jack 1968; Moore et al. 1973; Pelz 1978). Similar approaches are area overlap indices (AOI), which describe competition as the sum of the overlap of the influence areas of each neighbor with 
Table 1 Silvicultural prescriptions for regulating mixed tree species experiments. Examples are presented in alphabetical order

\begin{tabular}{|c|c|c|c|c|}
\hline Tree species combination & Research question & Factor regime & $\begin{array}{l}\text { Quantitative } \\
\text { measures for regulation }\end{array}$ & References \\
\hline $\begin{array}{l}\text { P. pinaster, Quercus pyr- } \\
\text { enaica }\end{array}$ & $\begin{array}{l}\text { Growth response to thin- } \\
\text { ning }\end{array}$ & $\begin{array}{l}\text { Basal area. Mixing pro- } \\
\text { portion }\end{array}$ & $\begin{array}{l}\text { Basal area of dominating } \\
\text { species (P. pinaster) }\end{array}$ & Aldea et al. (2017) \\
\hline $\begin{array}{l}\text { Betulua sp., Alnus sp., } \\
\text { Pinus sylvestris, Picea } \\
\text { abies }\end{array}$ & Productivity & $\begin{array}{l}\text { Stand density reduction, } \\
\text { mixing proportion }\end{array}$ & $\begin{array}{l}\text { Volume removed } \\
\text { Standardized mixing } \\
\text { proportion }\end{array}$ & Beliajeva and Ischuk (2010) \\
\hline $\begin{array}{l}\text { Pinus sylvestris, Picea } \\
\text { abies }\end{array}$ & Growth, stem structure & Stand density reduction & $\begin{array}{l}\text { Volume removed } \\
\text { Standardized mixing } \\
\text { proportion }\end{array}$ & Danilov et al. (2014) \\
\hline $\begin{array}{l}\text { P. pinea, Quercus sp. Juni- } \\
\text { perus sp. }\end{array}$ & $\begin{array}{l}\text { Modeling } \\
\text { Competition } \\
\text { Functional complemen- } \\
\text { tarity }\end{array}$ & $\begin{array}{l}\text { Stand density } \\
\text { Age }\end{array}$ & $\begin{array}{l}\text { Stand basal area } \\
\text { Min. proportion of BA for } \\
\text { accompanying species }\end{array}$ & de-Dios-García et al. (2015) \\
\hline $\begin{array}{l}\text { Pinus sylvestris, Betula } \\
\text { pendula }\end{array}$ & $\begin{array}{l}\text { Volume yield, mean diam- } \\
\text { eter and height growth }\end{array}$ & $\begin{array}{l}\text { Strength and timing of } \\
\text { thinning }\end{array}$ & $\begin{array}{l}\text { Tree number removed } \\
\text { five year intervals of } \\
\text { interventions }\end{array}$ & Hynynen et al. $(2005,2011)$ \\
\hline $\begin{array}{l}\text { Picea abies, Picea sitch- } \\
\text { ensis }\end{array}$ & $\begin{array}{l}\text { Economic optimization } \\
\text { under climate change }\end{array}$ & Density & $\begin{array}{l}\text { Volume } \\
\text { proportion }\end{array}$ & $\begin{array}{l}\text { Jacobsen and Thorsen } \\
\text { (2003) }\end{array}$ \\
\hline $\begin{array}{l}\text { Quercus sp. and Fraxinus } \\
\text { sp. mixtures with Betulua } \\
\text { sp. and Alnus sp. }\end{array}$ & $\begin{array}{l}\text { (a) Crown development, } \\
\text { use of extra spacing of } \\
\text { different social class tree; } \\
\text { (b) Length and degree of } \\
\text { the volume increment } \\
\text { increase }\end{array}$ & $\begin{array}{l}\text { Stand density reduction, } \\
\text { mixing composition }\end{array}$ & $\begin{array}{l}\text { Diameter, height and } \\
\text { crown horizontal projec- } \\
\text { tion increment of A, B, } \\
\mathrm{C} \text { tree social classes after } \\
\text { intensive thinnings }\end{array}$ & $\begin{array}{l}\text { Kairiūkštis and Juodvalkis } \\
\text { (1985) }\end{array}$ \\
\hline Pica abies, Fagus sylvatica & Productivity increase & $\begin{array}{l}\text { Stand density, } \\
\text { mixing proportion }\end{array}$ & $\begin{array}{l}\text { Stand basal area, } \\
\text { basal area proportion }\end{array}$ & Kennel (1965) \\
\hline Pica abies, Betulua sp. & $\begin{array}{l}\text { Pure and mixed } \\
\text { understory growth }\end{array}$ & Stand density reduction & Volume removed & Lundqvist et al. (2014) \\
\hline $\begin{array}{l}12 \text { native tropical tree } \\
\text { species }\end{array}$ & $\begin{array}{l}\text { Growth and thinning reac- } \\
\text { tions }\end{array}$ & $\begin{array}{l}\text { Density, } \\
\text { stem form, vitality }\end{array}$ & $\begin{array}{l}2 \times \text { systematic removal of } \\
\text { rows, } \\
1 \times \text { selective thinning }\end{array}$ & Piotto et al. (2003) \\
\hline $\begin{array}{l}\text { P. sylvestris } \\
\text { Q. robur } \\
\text { Q. petrea } \\
\text { Betula pendula }\end{array}$ & $\begin{array}{l}\text { Overyielding, } \\
\text { Quality improvement }\end{array}$ & & $\begin{array}{l}\text { Standardized SDI } \\
\text { Standardized mixing } \\
\text { proportion }\end{array}$ & $\begin{array}{l}\text { Pretzsch et al. }(2013,2019 b) \\
\text { Liziniewicz et al. }(2016)\end{array}$ \\
\hline $\begin{array}{l}\text { Picea abies, Abies alba, } \\
\text { Fagus sylvatica }\end{array}$ & $\begin{array}{l}\text { Productivity } \\
\text { Natural regeneration }\end{array}$ & Stand density reduction & $\begin{array}{l}\text { Density reduction in rela- } \\
\text { tion to unthinned plots }\end{array}$ & Pretzsch et al. (2015b) \\
\hline $\begin{array}{l}\text { Betula pendula, Alnus sp., } \\
\text { Pinus sylvestris, Picea } \\
\text { abies }\end{array}$ & Stand composition & $\begin{array}{l}\text { Stand density reduction, } \\
\text { mixing proportion }\end{array}$ & $\begin{array}{l}\text { Volume removed } \\
\text { Standardized mixing } \\
\text { proportion }\end{array}$ & Zalesova et al. (2016) \\
\hline
\end{tabular}

respect to the tree, being the radius of the influence zone a function of the size and the species (Bella 1971; de-DiosGarcía et al. 2015). Finally, also competition indices (CI), for instance, based on stem diameter and distances (A-value according to Johann 1982), vertical angles (Pukkala et al. 1998), or light cone method (Pretzsch et al. 2002) can be used for steering for characterizing the competitive status of each tree and prescribing their treatment (remain or removal). For instance, they may be used for determining the target growing space for each tree, or the target level of inter- and intraspecific competition in the course of crop tree thinning. Neighbors may be removed until a setpoint of space or competition level is achieved. Competition indices may also be used for steering at the cohort level. In this case, a defined target distribution of frequencies of the indexes for each species (percentage of trees within a given class of competitioncomposition indices) may be achieved by thinning.

The steering based on individual competition indices or on frequency distributions is a quantitative analogon to the traditional qualitative description of individual trees, their position, and their removal according to Kraft (1884). More detailed classifications as introduced by Assman (1961), Kairiūkštis (1972), and Kairūkštis and Juodvalkis (2005) based among others on detailed crown and stem characteristics, tree age, and development phase may be useful for analyzing the productivity and structure of mixed stands but are too complex and qualitatively based for being applied for modeling or silvicultural steering mixed-species experiments. 
Finally, the description and characterization of the spatial arrangement at stand level can be approached by means of the bivariate spatial point pattern processes, as Ripley's cross-k function, in order to characterize whether the individuals of the different species are clustered, dispersed or randomly distributed, as well as the size of the patches (Pommerening 2002; Renshaw et al. 2009; del Río et al. 2016). A given prescription could also aim to attain a given target spatial pattern. Less restrictive prescriptions could focus on determining patch size and target number of trees per species in a patch (Graham and Jain 2005).

\section{Representation of silvicultural treatments in models}

In this section, we sketch the six main approaches how the tree number reduction and thinning prescriptions have been implemented in forest stand models (Table 2, Fig. 4). There are no principle differences in the technical integration of prescriptions for mixed and mono-specific stands (Bravo et al. 2019). However, the variety of treatment variants increases with the number of tree species and the structural heterogeneity of a stand. This means that a flexible integration of a library of different rules becomes much more important in case of mixed-species stands.

Models that simulate long-term successional processes do not consider forest management at all, as their focus is on the natural stand development under disturbances or climate change. Such models put emphasis on a realistic representation of competition, regeneration, and thus natural mortality (Fig. 4, concept 1). Typical examples are gap models (e.g., Köhler and Huth 1998, Shugart et al. 2018, further summarized by Bugmann 2001), and matrix models as summarized by Liang and Picard (2013). McCook (1994) give an overview of the underlying causalities and theories. Also models that aim at the understanding of climate and weather effects on carbon allocation do not consider the effects of forest management. Such physiological models put emphasis on the description of tree intrinsic processes (e.g., Grote and Pretzsch 2002, Grant et al. 2007, Grote et al. 2011, further summarized by Landsberg 2003).

In contrast, models for forest management consider stand development as dependent on the stock being removed over time (Fig. 4, concept 2). Well-established representatives of that group are descriptively based yield tables that beyond monospecific stands (e.g., Gehrhardt 1909) have even considered mixed stands (e.g., Wiedemann 1942). They are typically based on one defined thinning prescription, e.g., moderate thinning from below as in the Wiedemann yield table for pine (1943). Like yield tables for monospecific stands, also tables for mixed stands assume one statically defined strength of thinning and course of mixing proportions throughout the rotation. Such tables have been obtained from long-term experimental plots (Wiedemann 1942) or inventory plots (Payandeh and Wang 1996; Penner 2008), the latter for representing an average situation of managed stands being considered.

Stand simulators, e.g., by Assmann and Franz (1965), Franz (1974), Curtis et al. 1982), Nagel (1985) or von Gadow (1987), provide the basis of computer generated yield table constructions. They consider at least a basic description of thinning (Fig. 4, concept 2) in addition to natural mortality (Fig. 4, concept 1). Such a description may be a thinning curve (e.g., Assman and Franz 1965) or a proportion of maximum stand density. That straightforward representation of thinning is also part of simulators which put emphasis on a physiological description of growth, e.g., 3D-CMCC (Collalti et al. 2014), rather than on the spatially explicit description of interventions.

Concept 3 (Fig. 4, concept 3), moreover, enables the interactive steering of stand development. Such a phaserelated intervention is of particular relevance for the development of new thinning guidelines. Models which apply

Table 2 Examples of thinning prescriptions integrated in forest stand models

\begin{tabular}{|c|c|c|}
\hline Model approach & Guideline, rule, algorithm & References \\
\hline Yield table & $\begin{array}{l}\text { Basal area proportion } \\
\text { defined depending on age }\end{array}$ & $\begin{array}{l}\text { Bonnemann (1939), } \\
\text { Wiedemann (1942), Christmann (1949) }\end{array}$ \\
\hline $\begin{array}{l}\text { Mean tree and cumulative } \\
\text { stand variable based simulators }\end{array}$ & Tree number per hectare & Franz (1983) \\
\hline Distant-independent individual tree simulator & $\begin{array}{l}\text { Relative stand densities, basal area mixing propor- } \\
\text { tions, stem volume removal according to inventory } \\
\text { data }\end{array}$ & $\begin{array}{l}\text { Nagel (1985), Döbbeler and Spellmann } \\
\text { (2001), Döbbeler (2004) }\end{array}$ \\
\hline Spatially dependent individual tree simulator & Species-specific stand basal area curves & Pukkala et al. (1994) \\
\hline $\begin{array}{l}\text { Spatially dependent individual tree simulator } \\
\text { with optimizing tool for silvicultural treatment }\end{array}$ & $\begin{array}{l}\text { Species-specific stand basal area curves } \\
\text { and tree-size-specific removal based on } 3 \text { size classes }\end{array}$ & Pukkala et al. (1998) \\
\hline $\begin{array}{l}\text { Spatially explicit individual } \\
\text { tree simulator }\end{array}$ & $\begin{array}{l}\text { Species-specific tree number depending on } \\
\text { stand mean height }\end{array}$ & Pretzsch et al. (2002) \\
\hline Simulator in batch mode & $\begin{array}{l}\text { Species-specific tree number, growing area require- } \\
\text { ment and maximum stand density as reference }\end{array}$ & Schwaiger et al. (2018) \\
\hline
\end{tabular}




\section{concept 1}

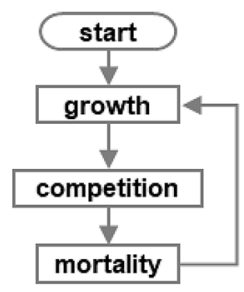

concept 2

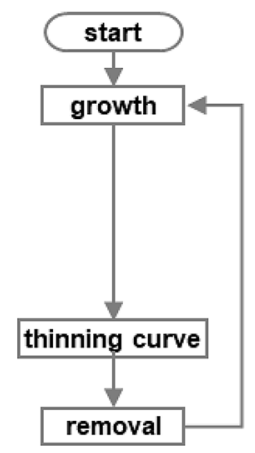

concept 4



concept 3

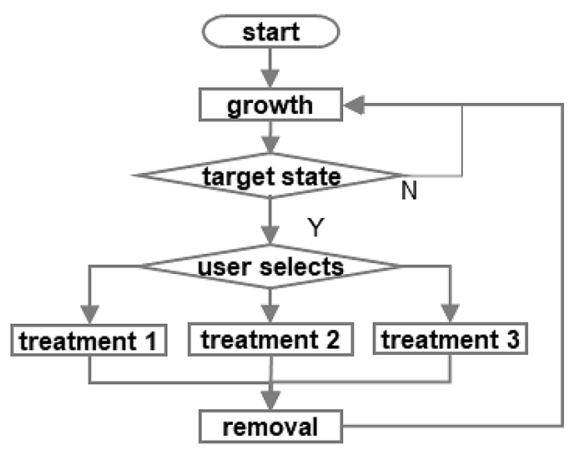

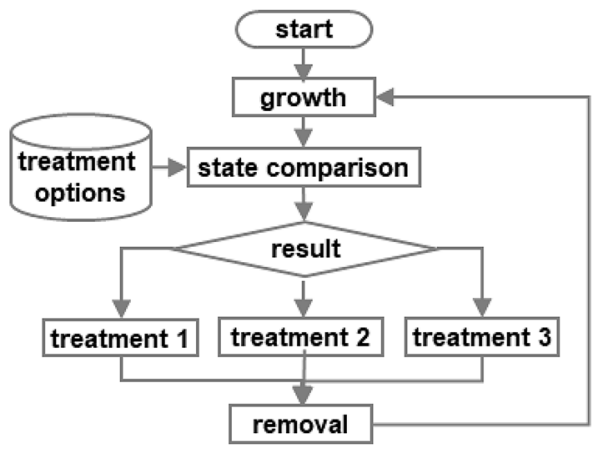

concept 6

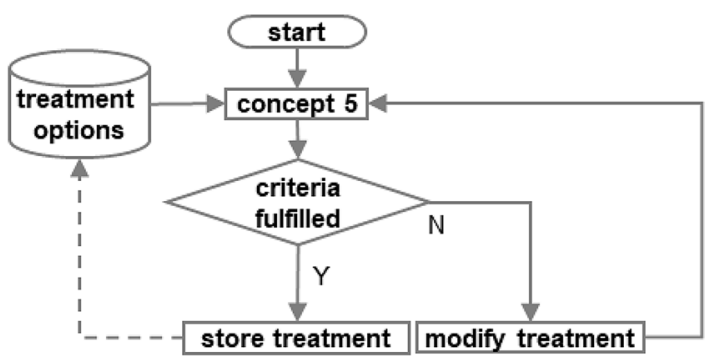

Fig. 4 Technical concepts of treatment implementation; concept 1 is typical for succession models, physiological or matrix models within their original field of application: thinning is an exclusive result of natural mortality; concept 2 is typical for models of concept 1 when extended for application in forestry: tree removal is an effect of thinning in addition, based on a thinning curve or a percentage of maximum density; concept 3 is typical for stand simulators when applied in education or consulting: the user selects from a group of alternative treatments, each time the system has come to a particular target state, e.g., given through stand age; concept 4 is typical for simulators applied within larger scale studies related to a whole forest management unit or landscape: the simulator determines the stand's developmental state based on stand statistics, such as a top height or the QMD and based of that current state selects a treatment rule, in order to approach a desired development. Simulator concept 5 is an extension to concept 4 that compares the stand's state (e.g., height, species composition) to a database that holds treatment instructions as dependent on stand state. The optimizer concept 6 embeds concept 5 into an optimization framework that steering concept are typically individual tree models (Pretzsch et al. 2015a). In many cases, concept 3 models consider the spatial stand structure and enable the selection of spatial explicit silvicultural treatment, such as crop tree selection or selective thinning. Such treatments often imply the definition of a target stand density given by a thinning curve, as in concept 2 . Users of concept 3 monitor stand development over time and select an appropriate treatment 
option interactively, e.g., per 5-year time step. For example, such an option has been implemented in PROGNAUS (Ledermann 2004) and in SILVA (Pretzsch et al. 2002). The BWINPro simulator by Nagel et al. (2006) enables a crop tree selection based on the following criteria: tree vitality, stem quality, relative tree dimension, distance between crop trees, and prescribed number of crop trees per species. Some individual tree models may refrain from the consideration of individual tree positions (e.g., PROGNAUS). Moreover, they may consider the effect of local competition in the vicinity of each individual tree and therefore consider the position of each individual tree growth and thinning (e.g., SILVA). Such distance-dependent individual tree models, if integrated into virtualization environments, even enable the selection of individual trees for felling on a per time-step basis (Roßmann et al. 2018).

If a model is to be applied in forest management and decision-making, the routinely simulation and comparison of various management pathways are a well-reasoned requirement. To reduce user interaction, the selection of the appropriate treatment per time step may be based on an indicator of the stand's developmental state, such as top height, instead of user input (concept 4, Fig. 4). Examples of models that use such a rule-based treatment simulation are ForCEEPS (Morin et al. 2011; Morin 2014), IBERO (Bravo et al. 2012), PINEA (Calama et al. 2007; Madrigal et al. 2009), PROGNAUS, and SILVA. Concepts 3 and 4 often apply to individual tree simulators and to distance dependent individual tree models, where each treatment may imply the selection of individual trees based on user interaction or model algorithms.

Simulation studies that consider whole forest management units or landscapes require the predefinition of adequate treatment based on stand attributes (Fig. 4e, concept 5 ). Such attributes may comprise the growth potential of the site being considered, the stand's species composition, and the developmental phase of the stand. That concept has often been implemented in individual tree models, such as HEUREKA (Wikström et al. 2011), PROGNAUS, and SILVA.

Simulations on the spatial levels of a forest management unit or landscape may aim at the optimization of wood production (Pukkala et al. 1998; Pukkala 2006) or on further target variables of multifunctional forestry (Öhman et al. 2011; Eggers et al. 2020). To this end, models that implement concept 5 have been embedded into optimization frameworks (summarized by Segura et al. 2014) which adjust the thinning concept in order to maximize an objective function (Fig. 4, concept 6). Such systems may even provide a variety of optimization algorithms (e.g., Pukkala 2009). Typically, the optimizer works on a set of simulation results that has yet been generated by the embedded simulation model (e.g., Pukkala 2009; Eggers et al. 2020).
The scope of eligible treatment schedules may be narrowed down to a subset of yet pre-configured options (Knoke 2012; Messerer et al. 2017; Hilmers et al. 2020).

\section{Representation of treatment in currently existing silvicultural guidelines for mixed stands}

Quantitatively formulated prescriptions for silvicultural treatment of monospecific stands are commonly presented for a specific set of conditions (e.g., age, site quality, species). Each rule should comprise kind, strength, and frequency of thinning (Schwaiger et al. 2018). The thinning prescription in Table 3 for mixed-species stands is analogously defined by a set of treatment rules, where each rule adheres to a particular period of stand development before the onset of regeneration cut and harvest.

Compared with the rules for mixed-species experiments (Table 2), the prescriptions for practical management are less sophisticated. The kind of thinning is often only indirectly addressed: In case of the selection of crop trees and subsequent release of them, the guideline prescribes a thinning from above (e.g., Bastien 1997; BaySF 2009; Llobet 2004).

The strength of thinning is mostly defined for the species assemblage in total or for the species separately, e.g., by the target tree number (Gonzalez-Molina 1996; Llobet 2004), basal area (BaySF 2009), target crown closure (Ryakhin and Kharitonova 1999), or \% of removed stand volume (Guovernement du Québec 2003).

The frequency of thinning is prescribed by intervals of years and ages (Llobet 2004) or height increment (GonzalezMolina 1996; Bastien 1997; Valkonen and Valsta 2001). The mixing proportion is regulated by the number of selected final crop trees (Bastien 1997; BaySF 2009), by the proportion of species-specific total tree number (Llobet 2004), basal area (Calama et al. 2020; Piqué et al. 2011, 2015), or standing volume (Gouvernement du Québec 2003). Thinnings are recommended to be repeated in defined n-year time steps in Lithuania (Juodvalkis and Kairiūkštis 2009). On some occasions, timing is not defined by a fixed value but for a fixed interval, as is the case of the prescriptions for mixed fir-beech forests in Provence Alps (CRPF-PACA 2004), where thinnings are prescribed on a fixed 15-20 yearintervals. Other prescriptions determine (Piqué et al. 2011) the moment of thinning by means of both dominant height and a given density that should be attained before applying thinning. However, characterization of the temporal aspect in mixtures using some size related trait (top height or mean diameter) results in additional complexity if species in the mixture have clearly different functional characteristics (e.g., one of them is occupying the dominant stratum). In this case, it is necessary to determine which species should be selected for promotion to fix the rule (commonly the dominating one, 


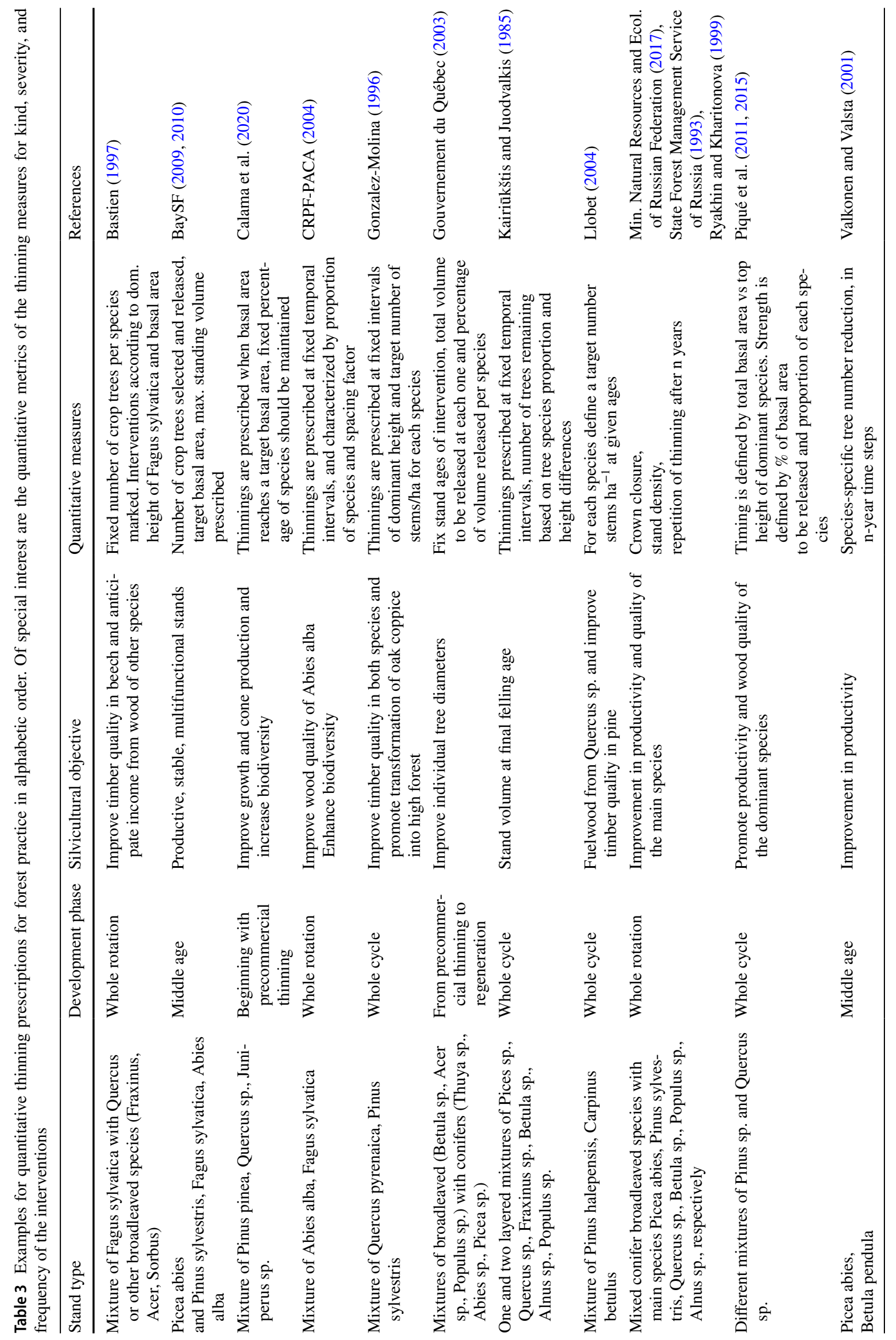


e.g., Bastien el al. 1997), or if prescriptions should consider both species (e.g., guidelines for mixtures of Pinus halepensis and Quercus ilex, Llobet 2004).

Thus, if compared with monospecific stands, thinning rules for mixtures often include at least two additional issues: the species, and the rate or proportion of each one. Prescriptions consider the spatial and temporal aspect of the intervention, together with the definition of the strength, and a detailed characterization on how to steer it. While a prescription should be defined at two different levels: standlevel and tree level, currently existing guidelines for steering mixed stands commonly lack of this detailed description (Table 3). Apart from stand-level prescriptions, downscaling stand-level decisions into tree level operation (i.e., selection of trees to be released) require more detailed descriptive procedures concerning, e.g., qualitative criteria for selecting trees to release or definition of the spatial arrangement of the mixture (Gonzalez-Molina 1996).

For stand-level decisions, available quantitative prescriptions are based on contrasting current stand stocking with a target stand stocking to be reached at a given developmental stage of the stand. That is the case of the prescriptions for mixed oak and sweet chestnut forests in North Spain (Principado de Asturias 2015) where thinning treatment is uniquely defined by means of dominant height of the stand, or prescriptions for mixtures of conifers, birch, and other broadleaved species in Québec (Gouvernment du Québec 2003), where stand age is the only driver defining interventions.

Timing of the first thinning in mixtures is a topic commonly ignored, fixing it based on rules for pure stands. However, it should be recommended to start earlier in mixtures than in monocultures, when first signs of between-species negative interactions are shown (Kerr and Haufe 2011, p. 37-38). This is especially important as noble hardwoods like Castanea sativa Mill., Ulmus sp., Sorbus domestica L. grow much slower than conifers (SW Europe), or Picea abies, Quercus sp., Fraxinus excelsior loose against Betula sp., and Populus tremula (NE Europe). In this sense, delayed thinnings is a common reason of loosing a significant proportion of valuable species and high-quality timber volume (Juodvalkis and Kairiūkštis 2009).

\section{Challenges, objectives, and concepts for further development of silvicultural prescriptions for mixed-species stands}

In this section, we will review the currently existing and under-development concepts and approaches for quantitatively assessing and describing thinning operation, paying special attention to the case of mixed stands. Table 4 shows which main aspects of tree species mixture may be considered, how they are described quantitatively, and the metrics we suggest for their quantitative description.

\section{Steering the spatial arrangement and temporal separation}

Mixtures in which one species gets ahead in height growth and exerts a strong shading effect on the admixed species may cause strong alien-thinning, segregation/demixing or even the complete loss of one species. Inter-specific competition may be reduced, and the mixture may be stabilized over time by spatially or temporally separating the constituent species (Figs. 5, a and b), i.e., by establishing each species in groups or clusters instead of intermixing the different species at wider spaced individual tree level. Another option is the establishment of the different species in different layers that have different ages instead of establishing a monolayered mixture like in case of beech and larch (Andrzejczyk

Table 4 Overview of various aspects of steering mixed-species stands and appropriate metrics, measures, and prescriptions that are under development (references are hardly available as most of the approaches are in the state of development and testing and not published yet)

\begin{tabular}{|c|c|}
\hline Aspects of steering mixed-species stands & Metrics, measures, prescriptions \\
\hline Spatial separation of inter-specific competition & $\begin{array}{l}\text { Standardized area definitions for troops, groups, etc. of mixing, } \\
\text { number of clusters per ha }\end{array}$ \\
\hline Temporal separation of inter-specific competition & $\begin{array}{l}\text { Quantification of lags between species establishment by } \Delta \text { time or } \Delta \text { tree height } \\
\text { between the species }\end{array}$ \\
\hline $\begin{array}{l}\text { Spacing, species-specific number of crop trees, thinning, } \\
\text { and competition regulation }\end{array}$ & $\begin{array}{l}\text { Species-specific crown size of mature dominant trees, } \\
\text { mean distances between mature trees, crown or growing area of dominant trees }\end{array}$ \\
\hline Species overarching mixing proportions & $\begin{array}{l}\text { Density equivalence coefficients, DEC, for species overarching steering of mixing } \\
\text { proportions, } \\
\text { percentages in terms of tree numbers, basal area, growing area, based on tree } \\
\text { number, basal area, SDI }\end{array}$ \\
\hline Species overarching stand density regulation & $\begin{array}{l}\text { Density modification coefficients, DMC, for considering species-specific increase } \\
\text { in packing density by mixing }\end{array}$ \\
\hline Individual tree removal criteria for different kind of thinning & $\begin{array}{l}\text { Competition indices, threshold tree-tree-distances, social classes, n-nearest neigh- } \\
\text { bors }\end{array}$ \\
\hline
\end{tabular}


Fig. 5 Measures of steering tree species mixtures by spatial or temporal separation. (a) The stronger the interspecific competition between tree species is, the more the tree species require a spatial separation in rows, groups or clusters to be maintained in the play. (b) Delayed establishment or temporal removal and restrain of species 2 may reduce inter-specific competition and outcompeting of one by the other tree species (Schütz 2002)

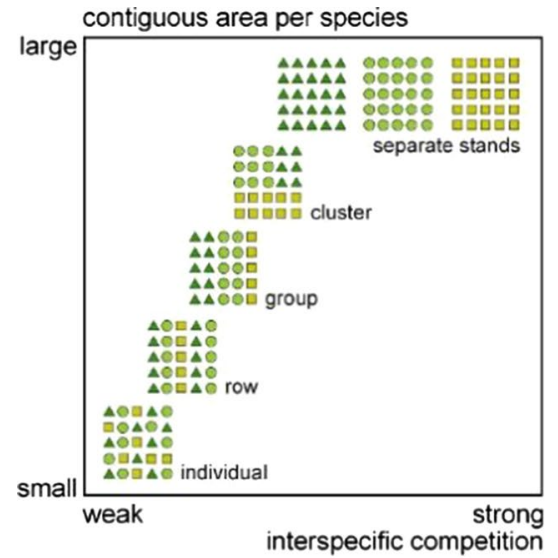

(a)

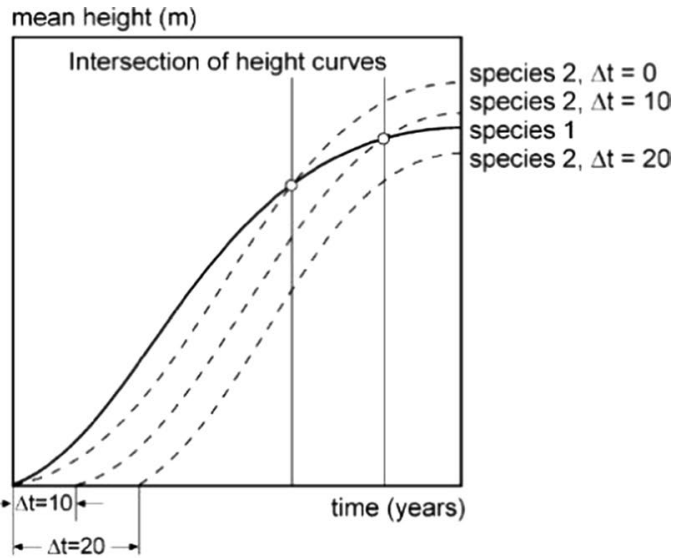

(b) et al. 2011) or Scots pine and European beech (Pretzsch et al. 2015c) on excellent sites.

A spatial or temporal separation of tree species as shown in Fig. 5 can be established by planting them in rows, groups, or clusters (Fig. 5a) or planting them with a temporal delay of some years or decades (Fig. 5b). In this way, the interspecific competition may be reduced in order to keep all species in the play. The size of a troop, group, and cluster may be defined by the contiguous area per species. The delay of establishment of a species may be defined by years or tree height difference.

Species combination with weak inter-specific competition might be established and kept in individual tree mixtures or small groups, whereas the pressure between species with strong competition may be reduced by spatial separation and cultivation in groups or clusters.

In the case of naturally regenerated stands (or plantations not initially considering the desired spatio-temporal arrangement), both the spatial and temporal separation may be achieved by species-specific removal or in the course of thinning interventions, and release of advanced natural regeneration (or underplanting) of the desired species (Bravo-Oviedo et al. 2014; Schütz 2002).
The design of the initial mixing pattern as well as the necessary silvicultural measures would benefit from a clear definition and quantification of mixing patterns. In the literature, the definition of mixing units such as troops, groups, or clusters is sometimes based on patch diameter (Niedersächsisches Ministerium für Ernährung, Land wirtschaft und Forsten 1987, Pretzsch 1997, 2009, p. 152). Mayer (1984, p. 297-298) described coarsely scaled mixing patterns as follows: cluster (diameter of the area at least as the height of a dominant tree of the species in mature age, i. e, $\approx 1000-5000$ $\mathrm{m}^{2}$ ), group ( growing area of about 5 mature trees of the respective species, i. e., $\approx 500-1000 \mathrm{~m}^{2}$ ), troop (growing area of less than 5 mature trees of the respective species, i. e., $\approx 50-500 \mathrm{~m}^{2}$ ). Burschel and Huss (1987) base the description of macro-structure on a multiple of the growing area requirement for mature trees (Burschel and Huss 1987).

A clear definition as exemplarily shown in Fig. 6a may help to clarify, standardize and establish reproducible pattern structures allied by guidelines for practice, experiments, and scenario analyses. A standardization may clarify the area units when establishing mixed stands by planting and also when shaping mixing patterns by silviculturally steering naturally regenerated mixed stands. Silvicultural operations
Fig. 6 Concepts for further developing silvicultural prescriptions for mixed-species stands. (a) Standardized area definitions for troops, groups, clusters of mixing. (b) Speciesspecific crown size and growing area development over stem size. (c) Equivalence coefficients may be derived for more species combination and based on species-specific slopes of the cpa-d relationship

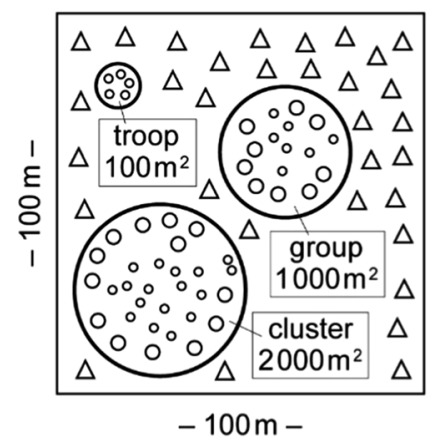

(a)

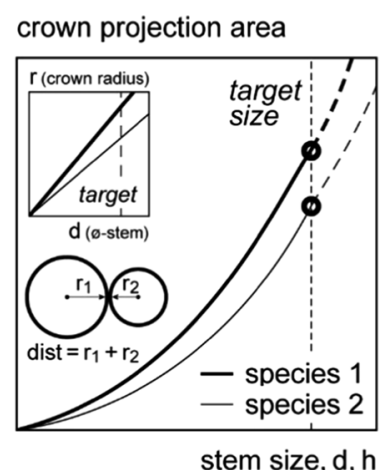

(b) equivalence coefficents



(c) 
in young stands often require a regulation of the mixing pattern and proportion by reducing inter-specific competition; this may be done by de-mixing of area units of defined sizes by elimination of one or the other tree species.

For standardizing overarching mixing experiments regarding the mixing patterns, it is not the assignment of the technical terms like troops, groups, etc. to defined areas, but the definition of the mixing structure by the number and size of the mixing units in $\mathrm{m}^{2}$ on a hectare. For the shaping of mixing units in naturally regenerated stands as well as for the establishing of gaps, a clear size information in terms of $\mathrm{m}^{2}$ is helpful.

\section{Species-specific growing area for steering mixing proportion and competition}

The species-specific crown projection area or growing area for a given or target stem diameter (Fig. 6b) is useful for initial spacing and spatial arrangement, for fixing the number of crop trees per species on a hectare and the target mixing proportion in the mature stand, and for distance and density regulation during stand development. Tree species with the same tree diameter can differ considerably in crown size

crown projection area $\left(\mathrm{m}^{2}\right)$

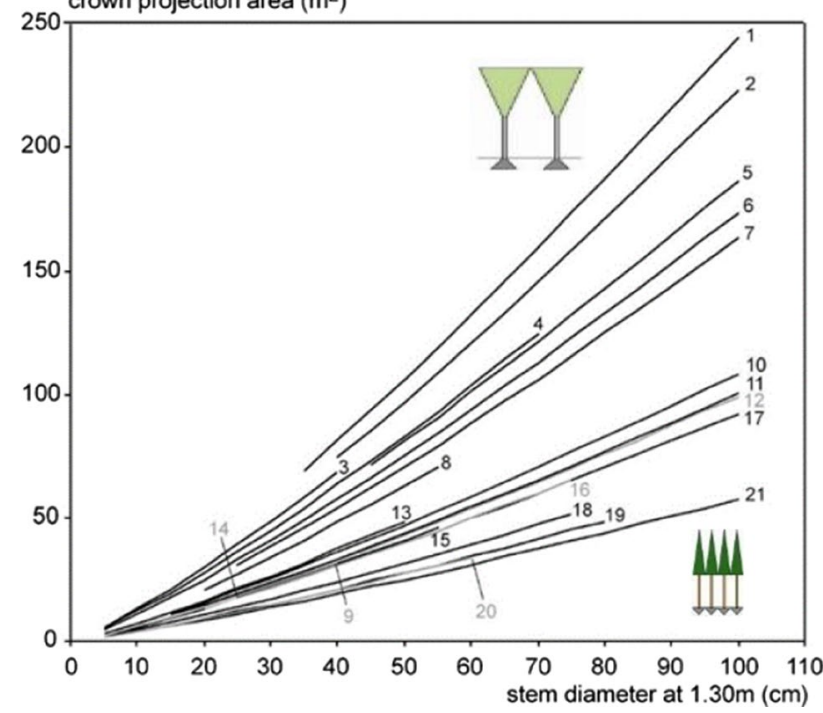

Fig. 7 Tree species of the same tree diameter can differ considerably in crown size and required growing space of dominant trees. This is demonstrated for (1) Quercus nigra L., (2) Platanus x hispanica MünchH., (3) Carpinus betulus L., (4) Tilia cordata Mıll., (5) Khaya senegalensis [DESR.] A. Juss., (6) Fagus sylvatica L., (7) Aesculus hippocastanum, (8) Robinia pseudoacacia L., (9) Alnus glutinosa [L.] Gaertn., (10) Araucaria cunninghamii Aiton ex. D.Don, (11) Pseudotsuga menziesii [Mirb.], (12) Abies alba MiLl., (13) Sorbus aucuparia L., (14) Betula pendula RoтH, (15) Acer pseudoplatanus L., (16) Abies sachalinensis MAst., (17) Ouercus petraea [MAтT.] Liebl., (18) Pinus sylvestris L., (19) Larix decidua MiLl., (20) Fraxinus excelsior L., (21) and Picea abies [L.] Karst. (after Pretzsch and Zenner 2017) and required growing space. Figure 7 shows this for selected tree species (1-21). Figure 7 reflects that, e.g., for a given tree diameter of $30 \mathrm{~cm}$, the mean crown area and growing space requirements can vary between 10 and nearly $50 \mathrm{~m}^{2}$ and, for a tree diameter of $100 \mathrm{~cm}$, the range is between 50 and $250 \mathrm{~m}^{2}$. The relationship between the crown size and growing space requirements of different species can be quantified by equivalence coefficients that indicate, for example, how much growing space a beech may need on average in relation to a spruce of approximately the same tree diameter and stem volume (see subsequent Sect. "Density equivalence coefficients for species overarching steering of mixing proportions").

Kairiūkštis and Juodvalkis (1985) provided analogously stem diameter-crown projection area relationships for trees of different social classes. Such crown projection areas and related tree-to-tree distances may be used for mixing and distance regulation in more structured stands. Crown size-tree diameter allometry for a given species in mixed stands may vary from the allometry observed in mono-specific stands (Pretzsch 2019a). Thus, definition of growing area may be also affected, and specific allometries should be developed for mixtures. Thus, while information on specific growing requirement shown in Figs. 7 and 8 may be a first basis, more detailed studies on this topic should be issue in the future.

The crown projection area values and the resulting radii may vary with site conditions and stand structure (species composition, mixing pattern, vertical structure). This requires further derivation of statistical relationships in order to better predict the final crop tree dimensions and space requirements; however, as long as such data are missing, the respective crown information from predominant trees or solitary trees growing in mono-specific stands (e.g., in

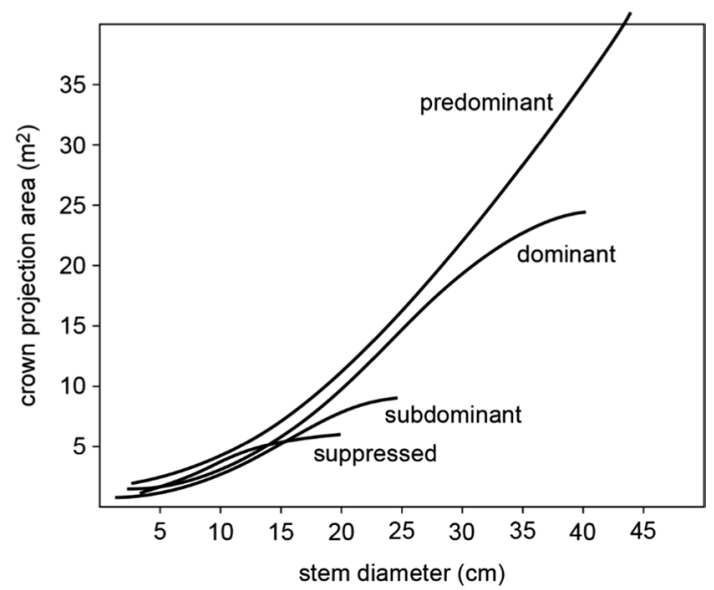

Fig. 8 Crown projection area and stem diameter relations for aspen (Populus tremula L.) depending on the stem diameter and the social position of the tree (adapted from Kairiūkštis and Juodvalkis 1985, p. 37, Fig. 3.4) 
Nelder trials see among others Kuehne et al. 2013; Vanclay 2006) may serve as a makeshift (first guess).

When determining the number of selected future crop trees and a density regulation based on number of trees per ha and species, it should be considered that the respective numbers need to be defined according to the space requirement of the respective tree species (Pretzsch and Zenner 2017). Examples for calculating species-specific tree-to-tree threshold distances and potential numbers of final crops trees are provided in Supplement Part A.

Different species-specific growing space requirements also need to be considered when regulating mixing proportions. Similarly, to achieve a desired tree number or standing volume per hectare, different species-specific growing space proportions may be required. Species-specific crown size-stem diameter relationships may be used as substitute for growing area requirement and for steering mixing proportion and density reduction by thinning (Hemery et al. 2005). In the case of spatially explicit guidelines, the crown size development of trees, and especially the crown growing area $c p a_{t a r}$ of trees when reaching their target diameter, is valuable. The relationship between tree size (stem diameter or tree height) and the crown projection area may be derived from available empirical research (Abetz 1974; Kairiūkštis and Juodvalkis 1985). Of special interest are the cpa $\mathrm{tar}_{\mathrm{ta}}$ values of the predominant trees at the target diameter $d_{t a r}$, as they can be supposed to have the size of the future crop trees. Figure $6 \mathrm{~b}$ shows the dependency of crown projection area as depending on species and stem diameter; the broken vertical line indicates the respective $c p a_{t a r}$ values when a tree arrives at $d_{\text {tar }}$.

\section{Density equivalence coefficients for species overarching steering of mixing proportions}

Recently, Pretzsch and del Río (2020) introduced speciesspecific density equivalence coefficients, DEC, that are suitable for the conversion of the stand density of one species into that of another species (Fig. 6c). In this way, DEC values enable the species-overarching analyses (Condes et al. 2017) and steering (Thurm and Pretzsch 2021) of spacing, stand density, and mixing proportion. The concept uses the DEC values for standardizing the density of all occurring species to a defined common reference species (e.g., Norway spruce, European beech). Examples for applying density equivalence coefficients for species overarching steering of mixing proportions are provided in Supplement Part B.

DEC depends strongly on the species combination. In the case of European beech, if mixed with Scots pine (Table 5b), the densities and changes of shape with increasing size growth differ less than if mixed with Norway spruce (Table 5a). Scots pine displays lower tree numbers than European beech at the beginning, but, with increasing diameter, the densities and growing space of both species converge.

The right upper corners of the matrix show DEC values when Norway spruce and Scots pine, respectively, have the greater growth and the bottom left corner when European

Table 5 Diameter-dependent density equivalence coefficient, $D E C_{E . b \rightarrow N . s p}$, for species combinations of species 1 Norway spruce and species 2 European beech (a) and $D E C_{E . b \rightarrow S . p}$ for species 1 Scots pine and species 2 European beech (b) (according to Pretzsch and del Río 2020)

(a)

\begin{tabular}{|c|c|c|c|c|c|c|}
\hline \multirow{2}{*}{$\frac{\mathrm{d}_{\mathrm{q}} \text { species } 2 \text { : }}{\text { E. beech }}$} & \multicolumn{6}{|c|}{$\mathrm{d}_{\mathrm{q}}$ species 1 : Norway spruce } \\
\hline & 10 & 20 & 25 & 30 & 40 & 50 \\
\hline 10 & 1.27 & 0.41 & 0.28 & 0.21 & 0.13 & 0.09 \\
\hline 20 & 4.70 & 1.50 & 1.04 & 0.77 & 0.48 & 0.33 \\
\hline 25 & 7.16 & 2.28 & 1.58 & 1.17 & 0.73 & 0.50 \\
\hline 30 & 10.10 & 3.22 & 2.23 & 1.65 & 1.03 & 0.71 \\
\hline 40 & 17.39 & 5.54 & 3.83 & 2.84 & 1.76 & 1.22 \\
\hline 50 & 26.49 & 8.44 & 5.84 & 4.32 & 2.69 & 1.86 \\
\hline
\end{tabular}

(b)

\begin{tabular}{|c|c|c|c|c|c|c|}
\hline \multirow{2}{*}{$\frac{\mathrm{d}_{\mathrm{q}}}{\text { E. beech }}$} & \multicolumn{6}{|c|}{$\mathrm{d}_{\mathrm{q}}$ of species 1: Scots pine } \\
\hline & 10 & 20 & 25 & 30 & 40 & 50 \\
\hline 10 & 0.85 & 0.24 & 0.16 & 0.12 & 0.07 & 0.05 \\
\hline 20 & 3.13 & 0.91 & 0.61 & 0.44 & 0.26 & 0.18 \\
\hline 25 & 4.77 & 1.38 & 0.93 & 0.67 & 0.40 & 0.27 \\
\hline 30 & 6.72 & 1.95 & 1.31 & 0.94 & 0.56 & 0.38 \\
\hline 40 & 11.57 & 3.35 & 2.25 & 1.62 & 0.97 & 0.65 \\
\hline 50 & 17.63 & 5.10 & 3.42 & 2.47 & 1.48 & 0.99 \\
\hline
\end{tabular}


beech has the lead in diameter growth. DEC values and their dependency on the species-specific stem diameters $d_{q 1}$ and $\mathrm{d}_{\mathrm{q} 2}$ will be used to adjust different tree species to the same scale level and to upscale from a standard scale to different species and species combinations.

Equivalence coefficients help to compare species and convert growing area requirements from one species to the other in order to steer mixing proportions (Sect. "Density Modification Coefficients for steering stand density and mixing proportions"). Due to the deficit of specific DEC coefficients for mixed stands, they were derived so far mainly from the allometric relationships between the crown projection area, cpa, and stem diameter, d, in mono-specific stands. However, we see the necessity of further developing equivalence coefficient concept by deriving such coefficients on a broader set of mono-specific and mixed stands and for a broader range of site conditions.

\section{Density Modification Coefficients for steering stand density and mixing proportions}

Another contrast to mono-specific stands is that mixedspecies stands may have higher maximum stand densities due to the niche complementary and higher packing density (Pretzsch 2014). Based on a broad comparison between the SDI values for mixed versus mono-specific stands, Pretzsch and Biber (2016) found mixed stands up to $36 \%$ denser.

To account for alterations induced by tree species mixing, the maximum stand density of the mono-specific stand may be modified through the concept of Density Modification Coefficients (DMC) introduced by Pretzsch and del Río (2020). The DMC is computed as the quotient of the maximum stand density of mixed stands divided by that of monospecific stands, derived from respective self-thinning lines. If the mean tree diameters of the two species are equal, the expression of DMC is the following: $\mathrm{DMC}=\left(\mathrm{N}_{1,(2)} /\right.$ $\left.\mathrm{DEC}_{\mathrm{sp} 2 \rightarrow \mathrm{sp} 1}+\mathrm{N}_{(1), 2}\right) / \mathrm{N}_{2}$. This coefficient was derived from long-term experiments for different tree species in mixtures. DMC values shown in Table 6 were calculated for sets of triplets of two mono-specific and one mixed-species stand. These values indicate that mixed stands had by $2-28 \%$ higher maximum stand densities, i.e., the density of monospecific stand should be multiplied by the DEC coefficients

Table 6 Mean ratios of mixed versus monospecific stand density, $\mathrm{DMC}$, for species combinations represented by data and analyzed so far

\begin{tabular}{llllll}
\hline $\begin{array}{l}\text { Species } \\
\text { combination }\end{array}$ & $\begin{array}{l}\text { N. spruce } \\
\text { E. beech }\end{array}$ & $\begin{array}{l}\text { s. oak } \\
\text { E. beech }\end{array}$ & $\begin{array}{l}\text { S. pine } \\
\text { E. beech }\end{array}$ & $\begin{array}{l}\text { Douglas-fir } \\
\text { E. beech }\end{array}$ & $\begin{array}{l}\text { S. pine } \\
\text { s. oak }\end{array}$ \\
\hline $\mathrm{n}$ & 178 & 254 & 32 & 18 & 36 \\
mean & 1.020 & 1.257 & 1.130 & 1.281 & 1.137 \\
$\mathrm{SE}$ & 0.015 & 0.046 & 0.054 & 0.141 & 0.040 \\
\hline
\end{tabular}

in order to estimate the maximum stand density of mixed stands of the given species combination. The resulting mean DMC values can be used for the example applications in next section.

In the following we show how density equivalence, DEC, and density modification coefficients, DMC, can be used in defining quantitative prescriptions for mixed stands. We start with the tree number per hectare, $\mathrm{N}$, and the quadratic mean diameter $d_{q}$ of a stand. Based on the $\ln (N)-\ln \left(d_{q}\right)$ relationship of a reference tree species $\left(N_{\text {ref,mono }}\right)$ in monospecific stands, the $\ln (N)-\ln \left(d_{q}\right)$ relationship of any other species (e.g., $N_{1, \text { mono }}, N_{2, \text { mono }}$ ) can be derived by density equivalence coefficients, DEC. Using the reference density $\left(N_{\text {ref,mono }}\right)$ in mono-specific stands, density modification coefficients, DMC, allow the estimation of the stand density of mixed-species stands $\left(N_{\text {ref,mixed }}\right)$. Based on $N_{\text {ref,mixed }}$, density equivalence coefficients may be applied for predicting the tree numbers of various mixing proportions. Furthermore, the maximum stand density $\left(N_{\text {ref,mixed }}\right)$ can be used as reference for scheduling the stand density reduction by thinning, resulting in a $\ln (N)-\ln \left(d_{q}\right)$ relationship as thinning prescriptions for both species in the mixture $\left(N_{1, \text { mixed,thinned }}, N_{2, \text { mixed,thinned }}\right)$.

In this way, the silvicultural regulation of mono-specific stands and mixed-species stands becomes a continuum; mono-specific stands represent a borderline case of mixedspecies stands. The introduced concept is suitable for design of silvicultural guidelines and the algorithms for their implementation in simulators for scenario analyses.

Figure 9 a shows that $N_{1, \text { mono }}, N_{2, \text { mono }}$ in monospecific stands can be derived by DEC from the tree number of a chosen reference tree species $N_{\text {ref,mono }}$, the tree numbers of a reference tree species in monospecific stands. The respective tree number $N_{\text {ref,mixed }}$ of this species in the mixed stand results from multiplication with DMC as shown in Fig. 9b. This means that the tree number of a reference tree species in the mixed stands can be derived by DMC, as they predict any general over- or underdensity of mixed versus monospecific stands. The maximum tree numbers $N_{1 \text { mixed }}, N_{2, \text { mixed }}$ for species 1 and 2 and a defined mixing proportion in mixedspecies stands can be calculated by respective DEC values shown in Fig. 9c. Finally, $N_{1, \text { mixed,thinned }}, N_{2, \text { mixed,thinned }}$ guide curves for tree numbers for defined thinning may be scheduled for both tree species in a mixture based on the maximum curves as reference (Fig. 9d).

In addition to the graphical explanation, Supplement Table 3 introduces the respective formulas for deriving the tree number by species in mixed stands from the tree number of a reference species in monospecific stands $\mathrm{N}_{1,2}$ for species proportions $\mathrm{m}$, defined by number of trees $\left(\mathrm{m}_{\mathrm{N} 1}\right.$ and $\left.\mathrm{m}_{\mathrm{N} 2}\right)$ or area $\left(\mathrm{m}_{\mathrm{A} 1}\right.$ and $\left.\mathrm{m}_{\mathrm{A} 2}\right)$. 




(a)

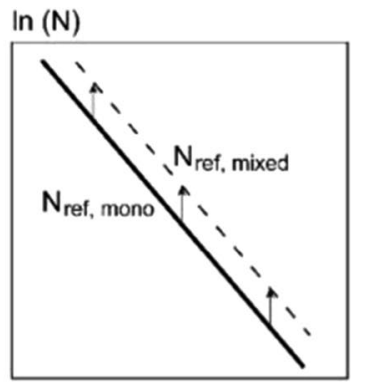

$\ln \left(d_{q}\right)$

(b)

Fig. 9 Application of species-specific coefficients DEC, for density equivalence, and DMC, for density modification, for density regulation in mixed-species stands based on the $\ln (N)-\ln \left(d_{q}\right)$ diagrams in schematic representation. Explanation in the text. (a) Based on the $\ln (N)-\ln \left(d_{q}\right)$ relationship of a reference tree species $\left(N_{\text {ref,mono }}\right)$ in mono-specific stands, the $\ln (N)-\ln \left(d_{q}\right)$ relationship of any other species (e.g., $N_{1, \text { mono }}, N_{2, \text { mono }}$ ) can be derived by density equivalence coefficients. (b) Based on the reference density $\left(N_{\text {ref,mono }}\right)$ in mono-

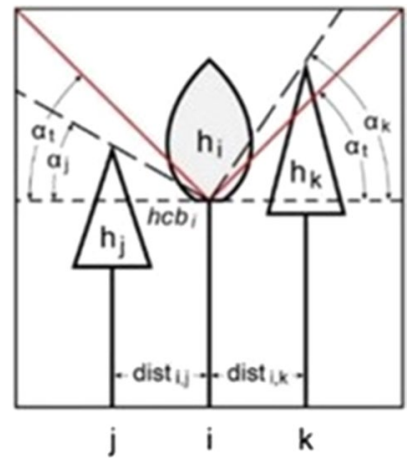

Fig. 10 Concepts for further developing silvicultural prescriptions for mixed-species stands. Individual tree-based removal criteria for different kinds of thinning

\section{Quantitative criteria for individual tree based removal criteria for different types of thinning}

The rules for removal of competitors of crop trees are based on information about the size and identity of the crop tree (Fig. 10, central tree i), the size and identity of the neighbors/competitors (Fig. 10, neighbor j, k...), and the distances $\left(\right.$ dist $\left._{i, j=1 \ldots n}\right)$ between crop tree and neighbors. The variables in Fig. 10 mean $h c b_{i}$ height to the crown base of the central tree, $\alpha_{i}$ angle between the horizontal and the crown tip of the neighbors, dist $_{i, j}$ tree-to-tree distance between central tree and its competitors, $\tan \alpha_{t}=45^{\circ}$ half opening angle of the virtual light cone; $\tan _{\alpha}$ opposite axis/adjacent axis, $\tan \alpha_{j}=\left(h_{j}-h c b_{i}\right) /$ dist $_{i, j}, \tan \alpha_{k}=\left(h_{k}-h c b_{i}\right) /$ dist $_{i, k}$ angle between the horizontal and the connecting line between height to the crown base of the central tree and the tips of

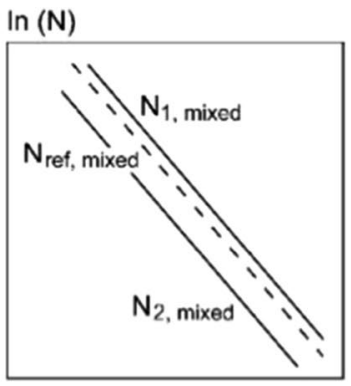

(c)

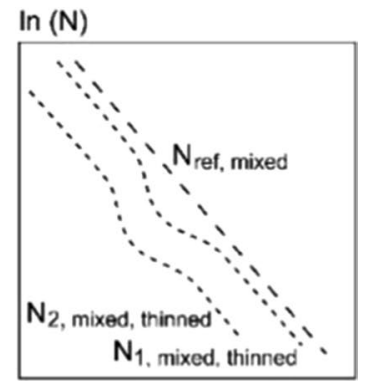

$\ln \left(d_{q}\right)$

(d) specific stands, density modification coefficients, DMC, allow the estimation of the stand density of mixed-species stands $\left(N_{\text {ref,mixed }}\right)$. (c) Based on $N_{\text {ref,mixed }}$, density equivalence coefficients may be applied for predicting the tree numbers of various mixing proportions. (d) Furthermore, the maximum stand density $\left(N_{\text {ref,mixed }}\right)$ can be used as reference for scheduling the stand density reduction by thinning, resulting in $\ln (N)-\ln \left(d_{q}\right)$ relationship as thinning prescriptions for both species in the mixture $\left(N_{1, \text { mixed,thinned }}, N_{2, \text { mixed,thinned }}\right)$

each neighbor. For an example of the quantification of the competition and competition release by removal of neighbors, see Supplement Part C.

\section{Auxiliary relationships}

\section{Maximum stand density as reference}

Steering of stand density means a reduction in the tree number below the level maximum stand density that is defined as the density of fully stocked stands under self-thinning conditions (Fig. 11a). In order to schedule the strength of thinning, i.e., of stand density reduction, the maximum stand density should be known. However, in contrast with mono-specific stands, knowledge is still scarce of the sitespecific stand density of mixed stands. We know that tree species mixing can change both the level and the slope of the self-thinning (Pretzsch and Biber 2016). Bravo-Oviedo et al. (2018b) found reasons for these changes, Ducey and Knapp (2010a, 2010b) provided metrics to quantify density in mixed-species stands, but empirical findings about density in mixed versus monospecific stands are still scarce.

One approach for filling knowledge gap may be the integration of unthinned mono-specific and mixed species plots when establishing thinning trials for mixed stands. Then, the density of the mixed plots may be used as a reference, and the other variants may be steered in dependence on the maximum density, e.g., by permanent or temporary reduction to 80,50 or $30 \%$ of the maximum stand density. More laborious but stable and more general and overarching in application is the derivation of general overarching site-specific maximum stand density lines for various tree species combinations. A makeshift may be multiplicators, introduced 
$\ln (\mathrm{N})$

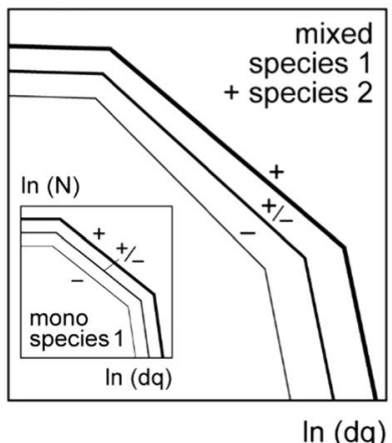

(a)

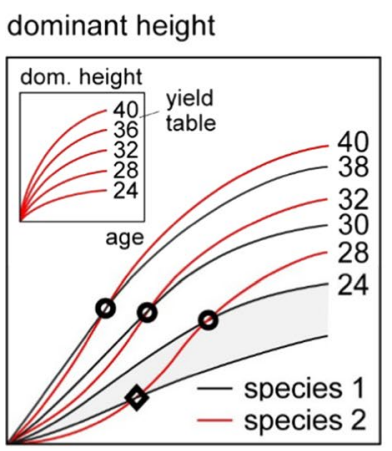

age

(b)

proportion growing area



proportion tree number

(c)
Fig. 11 Concepts for further developing silvicultural prescriptions for mixed-species stands. The main graphs address the concepts for mixed-species stands in schematic representation; the insertions in (a), (b) show the corresponding relationships for mono-specific stand. (a) Maximum stand density relationships for two-species stands on

by Pretzsch and del Río (2020), which enable the derivation of mixed stand density from monospecific stands by a set of multipliers (see Sect. "Density Modification Coefficients for steering stand density and mixing proportions").

In any case, the objective is to have relationships that reflect the maximum tree number, stand basal area, or stand volume depending on mean tree size or stand age for a defined species combination and specific site conditions as reference for quantifying and scheduling the strength of density reduction by thinning.

\section{Curves of tree height and height to crown base}

The site-specific age-height curve of a tree species indicates aspects of its fitness and the relationship between the height curves of different tree species reveal essential aspects of their inter-specific competition. An intersection of the specific height curves at early or mean ages as shown in Fig. 11b may cause strong competition or even the loss of the slower, lower, and inferior species first or of the outcompeted tree species in advanced stand ages. Competition may be released by a temporal distance between the establishment of the species or a removal of the dominating tree species in the neighborhood of the endangered trees of the other species. The site-specific height curves of mono-specific stands or even better the respective curves of the species in mixed stands are an essential component for developing thinning prescriptions (Petri 1978). The relationship between height curves may be used for deriving the necessary temporal distance $t$ between the establishment of the species, for the timing of the removal of the completion tree species, or even against establishing a special mixture at all in case that the competition will require too rich $(+)$, medium $( \pm)$, and poor $(-)$ sites in comparison with monospecific stands (see insertion bottom left). (b) Site-dependent curves of tree height and height to crown base. (c) Species-specific functions for transforming tree number-based mixing proportions to growing area-related mixing proportions

extensive steering activities. An additional valuable information may be the height to crown base curve as shown in Fig. $11 \mathrm{~b}$ exemplarily for species 1 and site index 24 . Both the intersection of the height curve of species 2 with the height to crown base curve (black diamond) and with the height curve (black circles) may be essential for developing the design of mixing, the strength and frequency of removal. The time when tree species 2 enters the crown space (gray area) of species 1 (see site indices 24) indicates the critical need of promoting tree species 1 by competition release, if species 1 should be kept in the stand. If species 1 is light demanding the critical distance must ensure slight distance between crowns.

The site-specific height curves of monospecific stands as shown for tree species 2 in the inserted graph top left may be a first orientation. However, more suitable for guidelines are the site-specific height curves for mixed stands as shown in the main graph; due to inter-specific competition they may differ. They can be developed, among others, based on unmanaged long-term experimental plots, or fully stocked and unmanaged inventory plots (Pretzsch 2019b; Mitscherlich 1970, 112-122).

\section{Species-specific relationships for transforming tree number based mixing proportions to growing area related mixing proportions}

The mixing proportions based on the tree number and growing area can be very different. Species with large crowns may have low tree numbers (and basal area and stand volume) proportions but high growing area proportions (Fig. 11c, curves above the bisector line). Species with similar crown allometry and growing space requirements may result in an 
equality of tree number based mixing proportions and growing area related mixing proportions (see Fig. 11c bisector line). A tree species with comparably low growing space requirements may result in curves below the bisector line (Fig. 11c). High tree and volume portions require underproportional shares of stand area (e.g., Norway spruce vs. European beech). The relationships can be used for steering mixing proportions; they allow to determine the space that should be reserved for a species in order to guarantee a target share to tree number or volume of this species (Pretzsch and Zenner 2017, Pretzsch and Río 2019). Further research should focus on developing such relationships for a broad range of tree species assemblages and different stand development phases (young, middle-aged mature).

\section{Further developed thinning algorithms for mixed-species stands}

In the following, we sketch the abstraction and algorithm which are in both the mind of a practical working silviculturist and the program code of a forest stand simulator when facing the task of thinning stands. Special attention will be drawn to aspects that additionally matter in mixed compared with monospecific stands. At any rate, we assume that a specific target state (goal) and prescription (guideline) have been defined for the situation at hand. With these preconditions in mind, we try to break down the complex algorithms for their realization into five main steps.

(i) Calibration for the respective environment and forest stand. For the treatment of mixed stands the site index per species, the expected overyielding and potential overdensity compared to monospecific stands are useful information. If there is overyielding, it is important to know if this is due to the profit of some species on the expense of the others or if a situation of mutual profit prevails.

As a basis for all subsequent steps, silvicultural steering requires information about the respective site (e.g., site conditions, the site index) and about the stand (e.g., species combination, past stand development).

(ii) Identification of the respective stand development phase. Here we need an assessment of the development phase for each species separately. In addition, the age or height difference between the species (symmetric/ asymmetric competitive pressure) is useful for scheduling species-specific interventions. Unlike in monospecific stands, a classification of a species ' development phase in mixed stands must consider that the characteristic variables (e.g., mean diameter) do not only depend from age and the treatment history; there is also a strong influence of interspecific interaction.
Therefore, the characteristic social status of a given species in a given stand has to be taken into account when assessing its development phase.

The stand development phase may be characterized by the mean or dominant diameter or height of the stand or by the age. When characterizing thinning interventions, most prescriptions distinguish between the sapling, pole and pre-mature forest stage.

(iii) Sapling stage. Here we apply metrics for scheduling the species-specific pattern of spatial distribution. On this stage rough species proportions are determined. For the fixation of the species-specific number of final crop trees and the mixing proportions, information of the final growing area requirement and the species overarching density is required. The interspecific spatial mixing pattern is also important in this context. If the competitive potentials of all species on a given site are about equal, a single-tree-wise mixture is feasible and often comes with positive structural side effects. If this is not the case, the area intended to be covered by one species must be divided into greater patches in order to guarantee the desired final situation.

Precommercial thinning by negative selection (e.g., elimination of predominant bad quality trees), tree number reduction, infrastructure provision (e.g., lanes and skid trails) for thinning.

(iv) Pole stage. Both the steering of the kind and the strength of thinning require information about the maximum density, the growing area requirement, and treeto-tree distances of crop trees for all the represented tree species. On this stage, improvement in species proportion in limited extent is still possible. In order to keep the final goal, species priorities have to be defined, like "in two of three cases when crop trees compete, remove a spruce in favor of a beech tree." Such considerations are of special importance at the border zones of patches covered by different species.

Most common is the schematic thinning without or selective thinning with selection of future crop trees. The kind of thinning may be scheduled by elimination of trees of defined social classes, competition indices, diameter range. In the case of selective thinning, the crop trees get released by elimination of competing neighbors. The strength of thinning may be defined at the stand level by setpoint remaining tree numbers, basal area, or standing volume. Or the strength of thinning may be defined at the individual tree level by the number of crop trees and the number of eliminated neighbors. Finally, the strength of thinning may be defined by combining tree and stand level as follows; a defined number of future crop trees are released (tree level definition) by the removal of their neighbors until 
a defined setpoint basal area is reached (stand level definition).

The frequency of thinning is commonly defined by recurrence every nth year or by defined intervals of height or diameter development (e.g., in steps of $3 \mathrm{~m}$ height increase).

A crucial information for scheduling the frequency of thinning is the height growth of the most inferior tree species if this should be kept in the play for the whole rotation. If the growth rate falls below a given threshold, a recurrence of thinning intervention may be due. However, as long as the situation of the most inferior species does not become critical, the opposite aspect, i.e., the height growth of the most dominant species, will serve as a good indicator for scheduling thinning intervals, because it represents the most rapid development going on, which shapes the growth conditions for all other species.

(v) Mature forest stage. All measures are analogous to the approach in mono-specific stands, however, the species specific growing area requirements, stand densities, and the species interactions in terms of overyielding and overdensity have to be taken into consideration. Thinning interval scheduling, species priorities, species patch sizes to be kept apply in the same way as pointed out above.

In this phase, again the steering of the kind, severity, and frequency of thinning are in the focus.

The kind of thinning mostly follows the kind of thinning chosen and started in the pole stage. The steering of the strength of thinning is no longer based on the tree number but on the basal area or SDI; due to the pro- gressing size differentiation, trees may have very different basal area and volumes and tree number becomes an equivocal metrics for steering density. In this stage, the size development (e.g., mean height) is often used as indicator for the frequency of thinning.

\section{The principles of regulation and steering for the development and application of silvicultural prescriptions}

Model-based scenario analysis may contribute to deriving an appropriate silvicultural objective and to derive silvicultural prescriptions for arriving at a given target state (Fig. 12). For this purpose, various treatment variants may be implemented algorithmically in a growth model, e.g., various tree number-mean tree height guidelines ( $\mathrm{N}-\mathrm{h}$-curves) for steering the stand development over time (Fig. 12a). For each of $i=1 \ldots n$ treatment options, the stand development is simulated and the result compared with the target. The treatment options which show the best approximation of the stand to the defined target may be of special interest in order to maintain a suitable guideline for practical application. The derivation is often based on a combination of a normative, an experimental, and a simulation approach and includes also ecological and socio-economical conditions.

The involvement of a scenario analysis requires a quantitative formulation of a set of treatment options and finally provides as a result a quantitatively based treatment option that might be used for target-oriented silvicultural steering in practice.

This model-based derivation of a silvicultural treatment guideline represents a regulation process. By definition



(a)

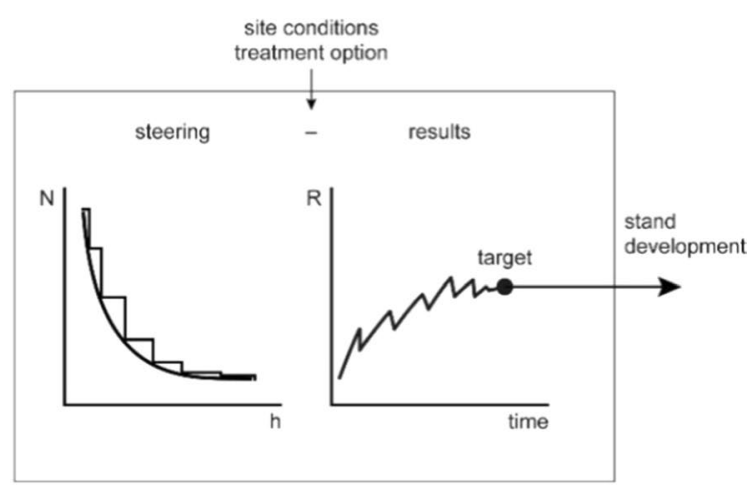

(b)
Fig. 12 Regulation process for the derivation of silvicultural prescriptions and steering process when applying selected silvicultural prescriptions in practice. (a) The effects of silvicultural treatments on the stand development may be simulated by a model. The stand development can be compared with the target, and the repeated modification of the treatment and simulation generates a set of scenarios with some of them appropriate for the defined target. The feedback between the simulated stand development and the treatment option makes this process a regulation. (b) A derived silvicultural treatment may be applied as silviculture guideline for stand management. As there is no feedback between stand development and guideline characteristics, this process is called steering 
(Berg and Kuhlmann 1993), regulation means that a development is controlled by the initial conditions, the time exogenous variables, and that the rules can be modified by a feedback between the current development and the applied rules (closed-loop-control).

The application of this once derived curve for stand treatment represents steering (Fig. 12b). Steering means that a system development is controlled just by the initial conditions, the time exogenous variables, and static rules (openloop control). In this case, once derived and prescribed rule (e. g., guideline curve or threshold) provides the set point stand characteristic (e.g., density, mixing proportion, number of future crop trees) to that, the stand is adjusted by silvicultural interventions in defined intervals. In the case of steering, there is no feedback between the stand development and the once fixed guideline. The application of a given silvicultural treatment in forest practice, i.e., the thinning of a stand based on a defined $\mathrm{N}-\mathrm{h}$ curve, represents steering.

\section{Conclusions}

Although forest practice has a wealth of experience of which objectives can be achieved and which aspects are relevant for goal achievement by mixed-species stands (e.g., density regulation, frequency of thinning, necessity of promoting one or the other species), this knowledge is hardly yet formulated quantitatively and algorithmic (Pretzsch and del Río 2020). Moreover, some of the existing quantitative silvicultural prescriptions are aimed for the reduction in mixed stands instead of promoting them (Ministry of Natural Resources and Ecology of Russian Federation 2017).

Silvicultural experts often refuse to develop or follow quantitatively formulated guidelines for complex forest stands. They may prefer a free style silviculture rather than feeling restricted in their creativity and flexibility by silvicultural prescriptions based on numbers (Brzeziecki et al. 2021, Diaci et al. 2011, Schädelin 1942, p. 95, Schütz 2002). However, purely qualitative based-expert approaches may have the disadvantages that they are situational based and less long-term target oriented. Their compliance and success are difficult to control. Quantitatively based silvicultural prescriptions, even being highly dependent on the large variability among site and within site conditions and the prevalence of numerous non-controlled factors, show convincing advantages over qualitative approaches also for complex mixed-species stands. By a quantitative description, silvicultural prescriptions become nonindividual related, objective, and transferable. By quantitative formulation, silvicultural prescriptions for mixed-species stands may be implemented as algorithms in simulation models. Quantitative formulation-despite of complexity-permits objectivity and reproducibility of defined prescriptions. Furthermore, quantitative formulations make the steering of experiments less individual related. They make it easier to steer stands in practice or long-term experiments continuously even under personal changeover. Already in the past, the length of employment of staff in practice and science for a given task was short related to forest cycles. However, at present many faculties, research stations, and forest enterprises increase the turnover of their staff members and reduce the length of responsibility for a given task. In both science and practice, a continuity in stand treatment is important and this is supported by quantitative silvicultural prescriptions.

We presented a further development of the steering of the spatial arrangement and temporal separation in mixed stands, the steering of the density and mixing proportion, and the steering of the species-specific growing space at the individual tree and stand level. The further development of respective prescriptions requires species-specific auxiliary relationships regarding the site-specific maximum stand density, the growing space requirement, and allometry of trees in mixed in contrast to monospecific stands. In sake of simplicity, we referred to two-species stands when introducing various approaches, methods, and measures in this review. However, all approaches can be analogously applied for mixtures with more than two tree species. Guidelines for management beyond the stand level, e.g., based on natural disturbance dynamics concepts, are similarly qualitative and require additional improvement in order to make them reproducible and implementable in simulators (Bergeron et a. 1999). Most of the reviewed prescriptions are based either on measures at the tree or at the stand level or on a combination of both (Table 4). However, many present silvicultural techniques presently work on a scale in between. They may tend, thin, remove trees, natural regenerate, or plant at the scale of macro-structure such as slits, gaps, troops, etc., and a combination and assembly of several structural patterns may be beginning with cable crane lines, proceeding with slits and gaps (Hilmers et al. 2020). Future prescriptions should standardize such patterns in shape and size, and model algorithms should be flexible enough to simulate the creation of such structures and the tree development on such sub-stand areas.

Algorithmic and modular formulation of silvicultural prescriptions enables their integration and use in tree and stand simulators for prognosis, scenario analyses, and development of future silvicultural guidelines. This is particularly relevant as the steering of mixed forest stands implies more degrees of freedom than that of pure stands. There is now an upcoming interest in harmonizing the implementation of thinning prescriptions through embedding of a common thinning module into the whole spectrum of simulators being applied. Such common use of a thinning module among different expert groups will be possible through an accordingly general module interface. Sharing thinning algorithms is 
particularly relevant, where novel thinning algorithms that take into account mixture effects are to be commonly implemented inside a variety of simulation models in order to be shared among international expert groups and make their scenario analyses better comparable.

A future challenge is to reconcile the subjective and often normative approaches by practitioners and the quantitatively based algorithms applied when steering experiments and scheduling thinning modules for stand simulators. Against that background, methods of artificial intelligence like deep neural networks that can be trained to mimic the decisions of experienced practitioners become a highly promising option.

Supplementary Information The online version contains supplementary material available at https://doi.org/10.1007/s10342-021-01388-7.

Acknowledgements The authors wish to thank the European Union for funding the projects "Mixed species forest management. Lowering risk, increasing resilience (REFORM)" (\# 2816ERA02S, PCIN2017026) under the framework of Sumforest ERA-NET. The study was furthermore funded through the 2017-2018 Belmont Forum and BiodivERsA joint call for research proposals, under the BiodivScen ERA-Net COFUND programme, and with the funding organization "Deutsche Forschungsgemeinschaft" (DFG).

The first and third authors thank the Bayerische Staatsforsten (BaySF) for supporting the establishment of new long-term experiments in Bavaria and the Bavarian State Ministry for Nutrition, Agriculture, and Forestry for funding new mixed forest experiments through the project W046 (\#7831-28364-2019) and for continuous funding of maintaining long term yield experiments (\#W07-7831-29098-2019). The fourth and fifth authors thank for grant funding (S-SUMFOREST-17-1) the Research Council of Lithuania. The last author acknowledges funding support from Spanish National Project (\#AGL-83828C2.1.R.). Thanks are also due to Jerry Vanclay, Miren del Río, Bill Mason, Sven Wagner, Jens Peter Skovsgaard, and Phil Comeau for supporting this review by providing literature. Many thanks to Dr. Kamil Bielak, University of Warsaw, for his critical pre-review and improvement in this manuscript. Finally, we thank two anonymous reviewers for their constructive criticism.

Author contributions HP and RC initiated and conceptualized the review, all authors reviewed the literature, HP, RC, WP wrote the manuscript, and GB, EM, EU revised the manuscript.

Funding Open Access funding enabled and organized by Projekt DEAL.

\section{Declarations}

Conflict of interest The author declares that he has no conflict of interest.

Open Access This article is licensed under a Creative Commons Attribution 4.0 International License, which permits use, sharing, adaptation, distribution and reproduction in any medium or format, as long as you give appropriate credit to the original author(s) and the source, provide a link to the Creative Commons licence, and indicate if changes were made. The images or other third party material in this article are included in the article's Creative Commons licence, unless indicated otherwise in a credit line to the material. If material is not included in the article's Creative Commons licence and your intended use is not permitted by statutory regulation or exceeds the permitted use, you will need to obtain permission directly from the copyright holder. To view a copy of this licence, visit http://creativecommons.org/licenses/by/4.0/.

\section{References}

Abetz P (1974) Zur Standraumregulierung in Mischbeständen und Auswahl von Zukunftsbäumen. AFZ 29(41):871-873

Abetz P (1988) Erwiderung zu Schober: Durchforstung nach Zahlen. AFJZ 10:174-183

Abetz P, Mitscherlich G (1969) Ü“berlegungen zur Planung von Bestandesbehandlungsversuchen. AFJZ 140:175-179

Aldea J, Bravo F, Bravo-Oviedo A, Ruiz-Peinado R, Rodríguez F, del Río M (2017) Thinning enhances the species-specific radial increment response to drought in Mediterranean pine-oak stands. Agr for Met 237-238:371-383

Ammer C (2008) Konkurrenzsteuerung-Anmerkungen zu einer Kernaufgabe des Waldbaus beim Aufbau vielfältiger Wälder. Eberswalder Forstliche Schriftenreihe 36(April):21-26

Amoroso MM, Turnblom EC (2006) Comparing productivity of pure and mixed Douglas-fir and western hemlock plantations in the Pacific Northwest. Can J for Res 36(6):1484-1496

Andrzejczyk T (2009) Dąb szypułkowy i bezszypułkowy. Hodowla. PWRiL. Warszawa. [Common and sessile oak. Silviculture. In Polish.]

Andrzejczyk T, Brzeziecki B (2018) Wpływ grabu (Carpinus betulus L.) na wzrost i przeżywalność dębu (Quercus robur L.) w fazie młodnika. Sylwan 162 (12):989-997. [Effect of hornbeam (Carpinus betulus L.) on growth and survival of pedunculate oak (Quercus robur L.) during the thicket stage. In Polish with English summary]

Andrzejczyk T, Bolibok L, Drozdowski S, Szeligowski H (2011) Sposób powstawania, struktura i produkcyjnooeæ drzewostanów bukowomodrzewiowych w Polsce. Leśne Prace Badawcze (Forest Research Papers), vol 72 (4): 301-310. (Polish beech-larch stands: their structure, productivity and processes of generation, in Polish with English summary).

Assmann E (1961) Waldertragskunde. Munchen-Bonn-Wien

Assmann E (1970) The principles of forest yield study. Pergamon Press, Oxford, New York, p 506

Assmann E, Franz F (1965) Vorläufige Fichten-Ertragstafel Für Bayern Forstw Cbl 84(1):13-43

Attocchi G (2015) Silviculture of oak for high-quality wood production. Dissertation SLU Alnarp, Acta Universitatis Agriculturae Sueciae, No 1652-6880:39

Bastien Y (1997) Pour l'education du hêtre en futaie claire et melangée. Rev for Fr 19:49-68

Bauhus J, Khanna PK, Menden N (2000) Aboveground and belowground interactions in mixed plantations of Eucalyptus globulus and Acacia mearnsii. Can J for Res 30(12):1886-1894

Bauhus J, Forrester DI, Gardiner B, Jactel H, Vallejo R, Pretzsch H (2017) Ecological stability of mixed-species forests. In MixedSpecies Forests, Springer, Berlin, Heidelberg, pp 337-382. https://doi.org/10.1007/978-3-662-54553-9

BaySF (2009) Bewirtschaftung von Fichten- und Fichtenmischbeständen. WNJF-RL-001. Bayerische Staatsforsten, Regensburg. [Management of pure and mixed spruce stands. Bavarians State Forestry, Regensburg, in German.]

BaySF (2010) Grundsätze zur Jungbestandspflege (JP) einschließlich Pflege unter Schirm (PUS) in der BaySF. WNJF-RL-003. Bayerische Staatsforsten, Regensburg. [Principles of early tending measures including tending below canopy. Bavarians State Forestry, Regensburg, in German.] 
Begon ME, Harper JL, Townsend CR (1998) Ökologie. Spektrum Akademischer Verlag, Heidelberg, p 750

Beliajeva NV, Ischuk TA (2010) Vlijanije rubok uhoda raznoj intensivnosti na obschuju proizvoditel'nost' drevostojev. Aktual'nyje problemy lesnogo kompleksa 25:3-6. 6. [The influence of thinnings of different intensity on stand productivity. In Russian.]

Bella IE (1971) A new competition model for individual trees. For Sci 17(3):364-372

Berg E, Kuhlmann F (1993) Systemanalyse und Simulation. Ulmer, Stuttgart, p 344

Bergeron Y, Harvey B, Leduc A, Gauthier S (1999) Forest management guidelines based on natural disturbance dynamics: standand forest-level considerations. For Chron 75(1):49-54

Bielak K, Dudzińska M, Pretzsch H (2014). Mixed stands of Scots pine (Pinus sylvestris L.) and Norway spruce [Picea abies (L.) Karst] can be more productive than monocultures. Evidence from over 100 years of observation of long-term experiments. For syst 23(3):573-589. https://doi.org/10.1007/s13595-017-0660-z

Bonnemann A (1939) Der gleichaltrige Mischbestand von Kiefer und Buche. Mitt Forstwirtsch u Forstwiss 10(4):45

Bravo F, Rodríguez F, Ordóñez C (2012) A web-based application to simulate alternatives for sustainable forest management: SIMANFOR. For Syst 21:4-8. https://doi.org/10.5424/fs/21122 11-01953

Bravo F, Fabrika M, Ammer C, Barreiro S, Bielak K, Coll L, .. BravoOviedo A (2019) Modelling approaches for mixed forests dynamics prognosis. Research gaps and opportunities. For Syst 28(1) eR002

Bravo-Oviedo A, Pretzsch H, Ammer C, Andenmatten E, Barbati A, Barreiro S et al (2014) European Mixed Forests: definition and research perspectives. Forest Syst 23:518-533. https://doi.org/ 10.5424/fs/2014233-06256

Bravo-Oviedo A, Condes S, del Río M, Pretzsch H, Ducey MJ (2018) Maximum stand density strongly depends on species-specific wood stability, shade and drought tolerance. Forestry. https:// doi.org/10.1093/forestry/cpy006

Bravo-Oviedo A, Pretzsch H, del Río M (2018a) Dynamics, Silviculture and Management of Mixed Forests. Managing Forest Ecosystems 31, Springer Berlin, Heidelberg, p 420

Bristow M, Vanclay JK, Brooks L, Hunt M (2006) Growth and species interactions of Eucalyptus pellita in a mixed and monoculture plantation in the humid tropics of north Queensland. For Ecol Manage 233(2-3):285-294

Brown GS (1965) Point density in stems per acre. New Zealand For Res Note 38, Wellington, New Zealand. p 12

Brus DJ, Hengeveld GM, Walvoort DJJ, Goedhart PW, Heidema AH, Nabuurs GJ, Gunia K (2012) Statistical mapping of tree species over Europe. Eur J Forest Res 131(1):145-157

Brzeziecki B, Drozdowski S, Bielak K, Czacharowski M, Zajączkowski J, Buraczyk W, Gawron L (2021) A demographic equilibrium approach to stocking control in mixed, multiaged stands in Bialowieża Forest, northeast Poland. For Ecol Manage 481:118694. https://doi.org/10.1016/j.foreco.2020.118694

Bugmann H (2001) A review of forest gap models. Clim Change 51(3-4):259-305

Burschel P, Huss J (1987) Grundriß des Waldbaus. Pareys Studientexte 49, Hamburg, Berlin, $352 \mathrm{p}$

Calama R, Sánchez-González M, Montero G (2007) Management oriented growth models for multifunctional Mediterranean forests: the case of stone pine (Pinus pinea L.) EFI Proceedings 56:57-70

Calama R, Gordo J, Madrigal G, Gonzalez A, Pardos M (2020) Esquema selvicultura para masas mixtas de Pinus pinea, Juniperus thurifera y Quercus sp. Technical report INIA-JCyL. https://sites.google.com/site/regeneracionnatural/proyecto-rta20 13-00011-c02-00/resultados/esquemas-de-selvicultura-actual. Accessed 27 April 2021
Christmann (1949) Ertragstafel für Kiefern-Fichten-Mischbestand. In: Wiedemann E (ed) Ertragstafeln der wichtigsten Holzarten bei verschiedener Durchforstung sowie einiger Mischbestandsformen. Schaper, Hannover, $100 \mathrm{p}$

Coll L, Ameztegui A, Collet C, Löf M, Mason B, Pach M et al (2018) Knowledge gaps about mixed forests: What do European forest managers want to know and what answers can science provide? For Ecol Manage 407:106-115

Collalti A, Perugini L, Santini M, Chiti T, Nolè A, Matteucci G, Valentini R (2014) A process-based model to simulate growth in forests with complex structure: Evaluation and use of 3D-CMCC Forest Ecosystem Model in a deciduous forest in Central Italy. Ecol Model 272:362-378

Condés S, Vallet P, Bielak K, Bravo-Oviedo A, Coll L, Ducey MJ et al (2017) Climate influences on the maximum size-density relationship in Scots pine (Pinus sylvestris L.) and European beech (Fagus sylvatica L.) stands. For Ecol Manage 385:295-307

CRPF-PACA (2004) Schems Regionaux de Gestion Sylvicole por Provence Alpes Cote d'Azur

Curtis RO, Clendenen GW, Reukema DC, De Mars DJ (1982) Yield tables for managed stands of coast Douglas-fir. General Technical Report PNW-135. Portland, OR: USDA, Forest and Range Experimental Station

Danilov DA, Beliajeva NV, Kovaliov NV (2014). Vlijanije rubok uhoda na rost i tovarnuju strukturu smeshannykh drevostojev sosny i jeli kislichnogo tipa lesa. Lesotekhnicheskij zhurnal (2):31-36. [The effect of thinnings on growth and stem structure of mixed Scots pine and Norway spruce stands of Oxalidosa forest type. In Russian.]

de-Dios-García J, Pardos M, Calama R, (2015) Interannual variability in competitive effects in mixed and monospecific forests of Mediterranean stone pine. For Ecol Manage 358:230-239

del Río M, Pretzsch H, Alberdi I, Bielak K, Bravo F, Brunner A et al (2016) Characterization of the structure, dynamics, and productivity of mixed-species stands: review and perspectives. European J For Res 135(1):23-49. https://doi.org/10.1007/ s10342-015-0927-6

Diaci J, Kerr G, O'Hara K (2011) Twenty-first century forestry: integrating ecologically based, uneven-aged silviculture with increased demands on forests. Forestry 84(5):463-465. https:// doi.org/10.1093/forestry/cpr053

Dirnberger GF, Sterba H (2014) A comparison of different methods to estimate species proportions by area in mixed stands. For Syst 23(3):534-546

Döbbeler H (2004). Simulation and evaluation of silvicultural treatments under current and changed climate conditions with the Forest Growth Model SILVA 2.2. Dissertation, Göttingen University, Göttingen

Döbbeler H, Spellmann H (2001) Methodological approach to simulate and evaluate silvicultural strategies under climate change. German forest sector under global change. Forstwiss Centralb 121(Suppl 1):52-69

Gouvernement du Québec (2003) Manuel amenagement forestiere. https://mffp.gouv.qc.ca/publications/forets/amenagement/ manuel.pdf

Ducey MJ, Knapp RA (2010) Rapid assessment of relative density in mixed-species stands of the northeastern United States. Int J for Res 2010:1-8. https://doi.org/10.1155/2010/212068

Ducey MJ, Knapp RA (2010) A stand density index for complex mixed species forests in the northeastern United States. For Ecol Manage 260(9):1613-1622

Ducey MJ, Woodall CW, Bravo-Oviedo A (2017) Climate and species functional traits influence maximum live tree stocking in the Lake States, USA. For Ecol Manage 386:51-61 
Eggers J, Räty M, Öhman K, Snäll T (2020). How well do stakeholderdefined forest management scenarios balance economic and ecological forest values? Forests 11(1). https://doi.org/10.3390/ f11010086

Erickson HE, Harrington CA, Marshall DD (2009) Tree growth at stand and individual scales in two dual-species mixture experiments in southern Washington State, USA. Can J for Res 39(6):1119-1132

Fabrika M, Ďurský J (2005) Algorithms and software solution of thinning models for SIBYLA growth simulator. J for Sci 51(10):431-445

Fahlvik N, Ekö PM, Petersson N (2015) Effects of precommercial thinning strategies on stand structure and growth in a mixed evenaged stand of Scots pine, Norway spruce and birch in southern Sweden. Silva Fennica 49(3)

Felton A, Lindbladh M, Brunet J, Fritz Ö (2010) Replacing coniferous monocultures with mixed-species production stands: an assessment of the potential benefits for forest biodiversity in northern Europe. For Ecol Manage 260(6):939-947

Forrester DI (2014) The spatial and temporal dynamics of species interactions in mixed-species forests: from pattern to process. For Ecol Manage 312:282-292

Forrester DI, Bauhus J, Cowie AL (2005) Nutrient cycling in a mixedspecies plantation of Eucalyptus globulus and Acacia mearnsii. Can J for Res 35(12):2942-2950. https://doi.org/10.1139/ $\mathrm{x} 05-214$

Forrester DI, Bauhus J, Cowie AL, Vanclay JK (2006) Mixed-species plantations of Eucalyptus with nitrogen-fixing trees: a review. For Ecol Manage 233(2-3):211-230

Franz F (1974) Zur Fortentwicklung der Durchforstungsverfahren aus der Sicht der Waldertragskunde. Forstarchiv 45(2/3):28-34

Franz F (1983) Zur Behandlung und Wuchsleistung der Kiefer. Forstwissenschaftliches Centralblatt 102(1):18-36

Gehrhardt E (1909) Über Bestandes-Wachstumsgesetze und ihre Anwendung zur Aufstellung von Ertragstafeln. Allgemeine Forstund Jagdzeitung 85:117-128. [About laws of stand-growth and their application for yield-tables. In German.]

Goelz JCG (2001) Systematic experimental designs for mixed species plantings. Nat Plants J 2(2):90-96

Gonzalez de Andres E, Seely B, Blanco JA, Imbert JB, Lo YH, Castillo FJ (2017) Increased complementarity in water-limited environments in Scots pine and European beech mixtures under climate change. Ecohydrology 10(2):e1810

Gonzalez-Molina J (1996) Tipificación de las masas mixtas de pino y rebollo en el centro de españa y desarrollo de conceptos para su tratamiento selvicola. Cuadernos SECF 3:147-165

Graham RT, Jai TB (2005) Application of free selection in mixed forests of the inland northwestern United States. For Ecol Manage 209:131-145

Grant RF, Black TA, Humphreys ER, Morgenstern K (2007) Changes in net ecosystem productivity with forest age following clearcutting of a coastal Douglas-fir forest: testing a mathematical model with eddy covariance measurements along a forest chronosequence. Tree Physiol 27(1):115-131

Griess VC, Knoke T (2011) Growth performance, windthrow, and insects: meta-analyses of parameters influencing performance of mixed-species stands in boreal and northern temperate biomes. Can J for Res 41(6): 1141-1159

Grote R, Pretzsch H (2002) A model for individual tree development based on physiological processes. Plant Biol 4(2):167-180. https://doi.org/10.1055/s-2002-25743

Grote R, Korhonen J, Mammarella I (2011) Challenges for evaluating process-based models of gas exchange at forest sites with fetches of various species. For Syst 20(3):389-406

Harper JL (1977) Population Biology of Plants. Academic Press, London, New York
Helms JA (1998) The dictionary of forestry. The Society of American Foresters, Bethesda, MD

Hemery GE, Savill PS, Pryor SN (2005) Applications of the crown diameter-stem diameter relationship for different species of broadleaved trees. For Ecol Manage 215(1-3):285-294

Hilmers T, Biber P, Knoke T, Pretzsch H (2020) Assessing transformation scenarios from pure Norway spruce to mixed unevenaged forests in mountain areas. Eur J For Res 139(4): 567-584. https://doi.org/10.1007/s10342-020-01270-y

Hochbichler E (1993) Methods of oak silviculture in Austria. Ann for Sci 50(6):583-591

Hynynen J, Ahtikoski A, Siitonen J, Sievänen R, Liski J (2005) Applying the MOTTI simulator to analyse the effects of alternative management schedules on timber and non-timber production. For Ecol Manage 207(1-2 SPEC. ISS.): 5-18. doi:https://doi.org/10.1016/j.foreco.2004.10.015

Hynynen J, Repola J, Mielikäinen K (2011) The effects of species mixture on the growth and yield of mid-rotation mixed stands of Scots pine and silver birch. For Ecol Manage 262(7):1174-1183

Jack WH (1968) Single trees sampling in evenaged plantations for survey and experimentation. 14th IUFRO Congress, München, pp 379-403

Jacobsen JB, Thorsen BJ (2003) A Danish example of optimal thinning strategies in mixed-species forest under changing growth conditions caused by climate change. For Ecol Manage 180(1-3):375-388

Jactel H, Gritti ES, Drössler L, Forrester DI, Mason WL, Morin X et al (2018) Positive biodiversity-productivity relationships in forests: climate matters. Biol Let 14(4):20170747

Jaworski A (2012) Hodowla lasu. Pielęgnowanie lasu. PWRiL Warszawa. pp 385. [Silviculture. Forest tending operations. In Polish.]

Johann K (1982). Der A-Wert, ein objektiver Parameter zur Bestimmung der Freistellungsstärke von Zentralbäumen. In Tagungsbericht, Deutscher Verband Forstlicher Versuchsanstalten - Sektion Ertragskunde, Weibersbrunn, pp 146-158 [The A-value, an objective criterion for estimating the release of central trees from competition. In German.]

Juchheim J, Annighöfer P, Ammer C, Calders K, Raumonen P, Seidel D (2017) How management intensity and neighborhood composition affect the structure of beech (Fagus sylvatica L.) trees. Trees 31(5): 1723-1735

Juodvalkis A, Kairiūkštis L (2009) Stand formation and cutting. Lutute, Kaunas, p 224 [In Lithuanian.]

Kairiūkštis L (1972) Scientific principles and practical methods of tending fellings and unclear cuttings in storeyed stands of the North-Western part of the U.S.S.R. Proceedings of the Seventh World Forestry Congress. Centro Cultural General San Martin, Buenos Aires (Argentina), 4-18 October 1972. vol 2, pp 1989-1998

Kairiūkštis L (1973) The Formation and thinning of mixed spruce/ deciduous stands. Mintis, Vilnius, p 358 [In Lithuanian]

Kairiūkštis L, Juodvalkis A (1985) The standard stands and their formation. Mokslas, Vilnius, p 244 [in Lithuanian]

Kairiūkštis L, Juodvalkis A (2005) The theoretical fundamentals of forming of the most productive stands. Balt for 11(2):38-50

Keane M, Mason B, Pfeifer A (2018). Species Mixtures in Irish Forests. COFORD, Department of Agriculture, Dublin

Kelty MJ (1992) Comparative productivity of monocultures and mixed-species stands. The ecology and silviculture of mixedspecies forests. Springer, Dordrecht, pp 125-141

Kelty MJ, Cameron IR (1995).Plot designs for the analysis of species interactions in mixed stands: the commonwealth. For Rev 322-332 
Kennel R (1965) Untersuchungen über die Leistung von Fichte und Buche im Rein- und Mischbestand. AFJZ 136:173-189

Kerr G (1996). The effect of heavy or 'free growth' thinning on oak (Quercus petraea and Q. robur). Forestry: An International. J For Res 69(4): 303-317

Kerr G, Haufe J (2011) Thinning practice: a silvicultural guide. Forestry Commission, vol. 1

Knoke T (2012). Forstbetriebsplanung. Ulmer, Stuttgart, Germany

Köhler P, Huth A (1998) The effects of tree species grouping in tropical rainforest modelling: simulations with the individual-based model FORMIND. Ecol Model 109(3):301-321

Kraft G (1884) Beiträge zur Lehre von den Durchforstungen, Schlagstellungen und Lichtungshieben. Klindworth's Verlag, Hannover, p 147 [Conrtributions to teaching about thinnings. In German.]

Kuehne C, Kublin E, Pyttel P, Bauhus J (2013) Growth and form of Quercus robur and Fraxinus excelsior respond distinctly different to initial growing space: results from 24-year-old Nelder experiments. J For Res 24(1):1-14

Landsberg J (2003) Physiology in forest models: history and the future. For Biometry Model Inf Sci 1(July):49-63

Larocque GR, Luckai N, Adhikary SN, Groot A, Bell FW, Sharma M (2013) Competition theory-science and application in mixed forest stands: review of experimental and modelling methods and suggestions for future research. Environ Rev 21:71-84. https:// doi.org/10.1139/er-2012-0033

Ledermann T (2004) PROGNAUS - ein Waldwachstumsmodell zur Fortschreibung von Inventurdaten, 2004. Bundesforschungs- und Ausbildungszentrum für Wald, Naturgefahren und Landschaft (BFW), Vienna, Austria. [PROGNAU—a forest growth model for inventory based prognosis. In German.]

Liang J, Picard N (2013) Matrix model of forest dynamics: an overview and outlook. For Sci 3(59):359-378. https://doi.org/10. 5849/forsci.11-123

Liang J, Crowther TW, Picard N, Wiser S, Zhou M, Alberti G et al (2016) Positive biodiversity-productivity relationship predominant in global forests. Science 354(6309):1-12

Liziniewicz M, Andrzejczyk T, Drozdowsk S (2016) The effect of birch removal on growth and quality of pedunculate oak in a 21-yearold mixed stand established by row planting. For Ecol Manage 364:165-172

Llobet S (2004) Propuesta de modelo selvícola para montes de pino carrasco (Pinus halepensis). In Modelos silvícolas en montes privados mediterráneos. Diputación Barcelona, p 182 [Suggestion of a silvicultural model for Aleppo pine forest. In Spanish.]

Lundqvist L, Mörling T, Valinger E (2014) Spruce and birch growth in pure and mixed stands in Sweden. For Chron 90(1):29-34

Madrigal G, Gordo J, Montero G, Calama R (2009). PINEA2 v1.0: aplicación informática para la gestión de las masas regulares de Pinus pinea L. en la Meseta Norte. Caso de estudio. Actas $5^{\circ}$ Congreso Forestal Español. ISBN: 978/84/936854/6-1 [IT application for silviculture of Pinus pinea L.. In Spanish].

Mason WL, Löf M, Pach M, Spathelf P (2018) The Development of Silvicultural Guidelines for Creating Mixed Forests. In: BravoOviedo A, Pretzsch H, del Río M (eds) Dynamics, Silviculture and Management of Mixed Forests. Managing Forest Ecosystems, vol 31. Springer, Cham, Germany

Mayer H (1984) Waldbau auf soziologisch-ökologischer Grundlage. Gustav Fischer Verlag, Stuttgart, New York, p 514

McCook LJ (1994) Understanding ecological community succession: causal models and theories, a review. Vegetatio 110(2):115-147

Messerer K, Pretzsch H, Knoke T (2017) A non-stochastic portfolio model for optimizing the transformation of an even-aged forest stand to continuous cover forestry when information about return fluctuation is incomplete. Ann For Sci 74(2): 45. https:// doi.org/10.1007/s13595-017-0643-0
Niedersächsisches Ministerium für Ernährung, Landwirtschaft und Forsten (1987) Anweisung zur Betriebsregelung (Forsteinrichtung) in den Niedersächsischen Landesforsten (B.A. 87), p 35

Ministry of Natural Resources and Ecology of Russian Federation (2017) Правила ухода за лесами. 2017. Министерство природных ресурсов и экологии Российской Федерации, 164 pp. [Forest tending rules. In Russian.]

Mitscherlich G (1970) Wald, Wachstum und Umwelt. 1. Band, Form und Wachstum von Baum und Bestand. JD Sauerländer's Verlag, Frankfurt am Main

Moore JA, Budelsky CA, Schlesinger RC (1973) A new index representing individual tree competitive status. Can J for Res $3: 495-500$

Morin X (2014) DISTIMACC, Tree species richness promotes productivity in temperate forests through strong complementarity between species. http://docs.gip-ecofor.org/public/bgf/BGF_ 20140916_DISTIMACC_Methodo.pdf. Accessed 14 May 2020

Morin X, Fahse L, Scherer-Lorenzen M, Bugman H (2011) Tree species richness promotes productivity in temperate forests through strong complementarity between species. Ecol Lett 14(12):1211-1219

Mosandl R, Kleinert A (1998) Development of oaks (Quercuspetraea (Matt.) Liebl.) emerged from bird-dispersed seeds under oldgrowth pine (Pinus silvestris L.) stands. Forest ecology and management 106(1):35-44

Nagel J (1985) Wachstumsmodell für Bergahorn in Schleswig-Holstein. Dissertation, Univ Göttingen, p 124

Nagel J, Duda H, Hansen J (2006) Forest Simulator BWINPro7. Forst U Holz 61:427-429

Neuner S, Albrecht A, Cullmann D, Engels F, Griess VC, Hahn WA et al (2015) Survival of Norway spruce remains higher in mixed stands under a dryer and warmer climate. Glob Change Biol 21(2):935-946

Nichols JD, Bristow M, Vanclay JK (2006) Mixed-species plantations: prospects and challenges. For Ecol Manage 233(2-3):383-390

Nowak CA (1995) Wood volume increment in thinned, 50- to 55-yearold, mixed-species Allegheny hardwoods. Can J for Res 26:819-835

Nyland RD (2016) Silviculture: concepts and applications. Waveland Press, $\mathrm{p} 680$

State Forest Management Service of Russia (1993) Основные положения по рубкам ухода в лесах России. 1993. Федеральная служба лесного хозяйства России, 35 p [Main regulations for thinnings in forests of Russia. In Russian]

Öhman K, Edenius L, Mikusiński G (2011) Optimizing spatial habitat suitability and timber revenue in long-term forest planning. Can J For Res 41(3): 543-551. https://doi.org/10.1139/X10-232

Olsthoorn AFM, Bartelink HH, Gardiner JJ, Pretzsch H, Hekhuis HJ, Franc A (1999) Management of mixed-species forest: silviculture and economics. IBN Scientific Contributions 15, Wageningen, DLO Institute for Forestry and Nature Research

Payandeh B, Wang Y (1996) Variable stocking yield functions for the boreal mixedwood in Ontario. For Chron 72(4):416-419. https:// doi.org/10.5558/tfc72416-4

Pelz DR (1978) Estimating individual tree growth with tree polygons. School of Forestry and Wildlife Res, Blacksburg, VA, FWS1-78, pp 172-178

Penner M (2008) Yield prediction for mixed species stands in boreal Ontario. For Chron 84(1):46-52. https://doi.org/10.5558/tfc84 046-1

Petri H (1978) Weiserflächen der Forsteinrichtung, standortsbezogene, ertragskundliche Auswertung von Fichten-Flächen für die Praxis. AFJZ 149 (5). [Experimental plots for forest management. In German] 
Piotto D (2008) A meta-analysis comparing tree growth in monocultures and mixed plantations. For Ecol Manage 255(3-4):781-786

Piotto D, Montagnini F, Ugalde L, Kanninen M (2003) Performance of forest plantations in small and medium-sized farms in the Atlantic lowlands of Costa Rica. For Ecol Manage 175(1-3):195-204

Piqué M, Beltrán M, Vericat P, Cervera T, Farriol R, Baiges T (2011) Models de gestió per als boscos de pi roig (Pinus sylvestris L.): producció de fusta i prevenció d'incendis forestals. Sèrie: Orientacions de gestió forestal sostenible per a Catalunya (ORGEST). Centre de la Propietat Forestal. Departament d'Agricultura, Ramaderia, Pesca, Alimentació i Medi Natural. Generalitat de Catalunya. http://cpf.gencat.cat/web/.content/or_organismes/ or04_centre_propietat_forestal/06-publicacions/publicacions_ tecniques/colleccions/orgest/models_de_gestio_forestal/orges t._models_de_gesti_per_als_boscos_de_pi_roig/docs/pi_roig. pdf. [Management models for stone pine. In Catalan.] Accessed 27 April 2021

Piqué M, Vericat P, Beltrán M, Calama R, Cervera T (2015) Models de gestió per a les pinedes de pi pinyer (Pinus pinea L.): producció de fusta i pinya i prevenció de incendis forestales. Centre de la Propietat Forestal. Departament d'Agricultura, Ramaderia, Pesca, Alimentació i Medi Natural. Generalitat de Catalunya. 133 p. ISBN: B17190-2015 [Management models for stone pine. In Catalan.]

Pommerening A (2002). Approaches to quantifying forest structures. For: Int J For Res 75(3):305-324

Pretzsch H (1997) Analysis and modeling of spatial stand structures. Methodological considerations based on mixed beech-larch stands in Lower Saxony. For Ecol Manage 97:237-253

Pretzsch H (2009) Forest dynamics, growth, and yield. in forest dynamics, growth and yield (pp. 1-39). Berlin, Heidelberg: Springer Berlin Heidelberg.

Pretzsch H (2014) Canopy space filling and tree crown morphology in mixed-species stands compared with monocultures. For Ecol Manage 327:251-264. https://doi.org/10.1016/j.foreco.2014.04. 027

Pretzsch H (2019a) The effect of tree crown allometry on community dynamics in mixed-species stands versus monocultures: a review and perspectives for modeling and silvicultural regulation. Forests 10 (9): 810. https://doi.org/10.3390/f10090810

Pretzsch, H (2019b). Weiterentwicklung der Dichte- und Mischungsregulierung forstwirtschaftlich wichtiger Baumarten. Äquivalenz-Koeffizienten und Dichte-Steigerungs-Koeffizienten für generische waldbauliche Behandlungsalgorithmen. AFJZ 190 (3/4): 55-72 [Innovations in density and mixture regulation. In German.]

Pretzsch H, Biber P (2016) Tree species mixing can increase maximum stand density. Can J For Res 46: 1179-1193.

Pretzsch H, del Río M (2020). Density regulation of mixed and monospecific forest stands as a continuum: a new concept based on species-specific coefficients for density equivalence and density modification. Forestry: an International J For Res 93(1):1-15. https://doi.org/10.1093/forestry/cpz069

Pretzsch H, Zenner EK (2017) Toward managing mixed-species stands: from parametrization to prescription. For Ecosyst 4(1): $19 \mathrm{https} / / /$ doi.org/10.1186/s40663-017-0105-Z

Pretzsch H, Biber P, Ďurský J (2002). The single tree-based stand simulator SILVA: construction, application and evaluation. For Ecol Manage 162:3-21.

Pretzsch H, Bielak K, Block J, Bruchwald A, Dieler J, Ehrhart HP et al (2013) Productivity of mixed versus pure stands of oak (Quercus petraea (M att.) L iebl. and Quercus robur L.) and European beech (Fagus sylvatica L.) along an ecological gradient. European J For Res 132(2):263-280.

Pretzsch H, Forrester DI, Rötzer T (2015a) Representation of species mixing in forest growth models: a review and perspective.
Ecol Modell 313:276-292. https://doi.org/10.1016/j.ecolm odel.2015.06.044

Pretzsch H., Biber P, Uhl E, Dauber E (2015b) Long-term stand dynamics of managed spruce-fir-beech mountain forests in Central Europe: structure, productivity and regeneration success. Forestry: An International J For Res 88(4):407-428. https://doi.org/10.1093/forestry/cpv013

Pretzsch H, del Río M, Ammer C, Avdagic A, Barbeito I, Bielak K et al (2015c) Growth and yield of mixed versus pure stands of Scots pine (Pinus sylvestris L.) and European beech (Fagus sylvatica L.) analysed along a productivity gradient through Europe. European J For Res 134(5):927-947. https://doi.org/ 10.1007/s10342-015-0900-4

Pretzsch H, Rötzer T, Forrester DI (2017) Modelling mixed-species forest stands. In: Pretzsch H, Forrester DI, Bauhus J (eds.) Mixed-species forests, S. 653, (pp. 383-432). Springer Berlin Heidelberg. DOI https://doi.org/10.1007/978-3-662-54553-9. [DOI]

Pretzsch H, Steckel M, Heym M, Biber P, Ammer C, Ehbrecht M, Bielak K, Bravo F et al (2020) Stand growth and structure of mixed species and monospecific stands of Scots pine (Pinus sylvestris L.) and oak (Q. robur L., Quercus petraea (Matt.) Liebl.) analysed along a productivity gradient through Europe. Eur J For Res 139(3):349-367. https://doi.org/10.1007/ s10342-019-01233-y

Principado de Asturias 2015. Catálogo de modelos selvícolas del Principado de Asturias y referente técnico de buenas prácticas de Gestión. Available online: https://www.asturias.es/Astur ias/descargas/PDF_TEMAS/Agricultura/Politica\%20Forestal/ planificacion/planificacion/monte/catalogo_de_modelos_selvi colas_inf_publica.pdf. Accessed 27 April 2021

Pukkala T (2006) Optimising the semi-continuous cover forestry of Finland. AFJZ 177(8/9):141-149

Pukkala T (2009) Population-based methods in the optimization of stand management. Silva Fenn 43(2):261-274. https://doi.org/ $10.14214 / \mathrm{sf} .211$

Pukkala T, Kolström T, Miina J (1994) A method for predicting tree dimensions in Scots pine and Norway spruce stands. For Ecol Manag 65(2-3):123-134. https://doi.org/10.1016/0378-1127(94) 90164-3

Pukkala T, Miina J, Kurttila M, Kolström T (1998) A spatial yield model for optimizing the thinning regime of mixed stands of Pinus sylvestris and Picea abies. Scand J for Res 13(1-4):31-42

Renshaw E, Comas C, Mateu J (2009) Analysis of forest thinning strategies through the development of space-time growthinteraction simulation models. Stoch Environ Res Risk Assess 23: 275-288. https://doi.org/10.1007/s00477-008-0214-x

Roßmann J, Schluse M, Hoppen M, Nägele G, Marquardt T, Averdung C, Poschenrieder W, Schwaiger F (2018) ClusterWIS revisited - an updated look at the decentralized forest information and management system. Int J Adv Netw Sci $11(3,4): 81-$ 91. ISSN 1942-2644

Rötzer T, Seifert T, Pretzsch H (2009) Modelling above and below ground carbon dynamics in a mixed beech and spruce stand influenced by climate. Eur J for Res 128(2):171-182

Ryakhin VA, Kharitonova OA (1999) Opyt rubok pereformirovanija listvenno-jelovyh nasazhdenij Tverskoj oblasti. Trudy lesoinzhenernogo fakul'teta PetrGU (2): 128-130 [The experience of reformation cuttings in mixed broadleaved-spruce stands of Tver region. In Russian]

Schädelin W (1942) Die Auslesedurchforstung als Erziehungsbetrieb höchster Wertleistung, 3rd edn. Verlag Paul Haupt, Bern, Leipzig, p 147

Schütz JP (2002) Silvicultural tools to develop irregular and diverse forest structures. Forestry 75(4):329-337 
Schwaiger F, Poschenrieder W, Biber P, Pretzsch H (2018) Species mixing regulation with respect to forest ecosystem service provision. Forests 9(10):632. https://doi.org/10.3390/f9100632

Schwappach A (1908) Die Kiefer. VerlagNeumann, Neudamm, p 180

Schwappach A (1911) Die Rotbuche. Verlag Neumann, Neudamm, p 231

Segura M, Ray D, Maroto C (2014) Decision support systems for forest management: A comparative analysis and assessment. Comput Electron Agric 101(January 2018): 55-67. https://doi.org/10. 1016/j.compag.2013.12.005

Shugart HH, Wang B, Fischer R, Ma J, Fang J, Yan X et al (2018) Gap models and their individual-based relatives in the assessment of the consequences of global change. Environ Res Lett 13(3):033001

Spellmann H (2008) Die Kiefer-ein Auslaufmodell? Beiträge für eine zielgerihtete Entwicklung. Beiträge aus der NW-FVA, Nordwestdeutsche Forstliche Versuchsanstalt (Hrsg.), Vol 2, p 63-78 [Scots pine-an outdated species? Contributions to a focused development,. In German.]

Scherer-Lorenzen M, Körner C, Schulze ED (eds) (2005) Forest diversity and function. Ecol Studies 176, Springer-Verlag, Berlin, p 399

Stimm K, Heym M, Uhl E, Tretter S, Pretzsch H (2021) Height growthrelated competitiveness of oak (Quercus petraea (Matt.) Liebl. and Quercus robur L.) under climate change in Central Europe. Is silvicultural assistance still required in mixed-species stands? For Ecol Manage 482:118780. https://doi.org/10.1016/j.foreco. 2020.118780

Thurm EA, Pretzsch H (2021) Growth-density relationship in mixed stands-Results from long-term experimental plots. For Ecol Manage 483:118909. https://doi.org/10.1016/j.foreco.2020. 118909

Valkonen S, Valsta L (2001) Productivity and economics of mixed twostoried spruce and birch stands in Southern Finland simulated with empirical models. For Ecol Manage 140(2-3):133-149
Vanclay JK (2006) Experiment designs to evaluate inter-and intraspecific interactions in mixed plantings of forest trees. For Ecol Manage 233(2-3):366-374

Vanclay JK, Lamb D, Erskine PD, Cameron DM (2013) Spatially explicit competition in a mixed planting of Araucaria cunninghamii and Flindersia brayleyana. Ann for Sci 70(6):611-619

Gadow von K (1987) Untersuchungen zur Konstruktion von Wuchsmodellen für schnellwüchsige Plantagenbaumarten. Forstl Forschungsber München 77, p 147 [Investigations for constructing growth models for fast gowing plantage tree species. In German.]

Wiedemann E (1942) Der gleichaltrige Fichten-Buchen-Mischbestand. Mitteilungen aus Forstwirtschaft und Forstwissenschaft 13(1). [The even-aged spruce and beech mixed forest stand. In German.]

Wiedemann E (1943) Kiefern-Ertragstafel für mäßige Durchforstung, starke Durchforstung und Lichtung, In: Wiedemann E (1948) Die Kiefer 1948. Verlag M \& H Schaper, Hannover, Germany, p 337

Wiedemann E (1951) Ertragskundliche und waldbauliche Grundlagen der Forstwirtschaft. Das Hauptergebnis der 70jährigen Arbeiten der (ehem.) Preußischen Forstlichen Versuchsanstalt. Sauerländer, Frankfurt a.M., Germany

Wikström P, Edenius L, Elfving B, Eriksson LO, Lämås T, Sonesson J, Öhman K, Wallerman J, Waller C, Klintebäck F (2011) The Heureka forestry decision support system: an overview. Math Comput for Nat Sci 3:87-94

Zalesova, ES, Ananjev EM, Berezhnov VA, Vedernikov EA, Gof AA, Zalesov VN, Savin VV (2016) Pereformirovanije proizvodnykh osinnikov v hvojnyje nasazhdenija rubkami uhoda. Aktual'nyje problemy lesnogo kompleksa 44: 27-30 [Reforming of acrivative aspen forest into evergreen forests by improvement belling methods. In Russian.]

Publisher's Note Springer Nature remains neutral with regard to jurisdictional claims in published maps and institutional affiliations. 